Arteriolenverengung zur Behandlung des Makulaödems im Tiermodel eines

Venenastverschlusses

\author{
Dissertation \\ zur Erlangung des akademischen Grades \\ Dr. med.
}

an der Medizinischen Fakultät

der Universität Leipzig

eingereicht von:

Martha Patricia Köferl, geboren am 06.11.1983 in Amberg

angefertigt in der Augenklinik der medizinischen Fakultät der Universität Leipzig

Betreuer: Prof. Dr. med. Peter Wiedemann, Prof. MUDr. Matus Rehak

Beschluss über die Verleihung des Doktorgrades vom: 15.01.2019 
Medizinische Fakultät der Universität Leipzig

\section{Einreichungserklärung}

Die von Martha Patricia Köferl

vorgelegte Dissertation wurde betreut von

Prof. Dr. med. Peter, Wiedemann, Prof. MUDr. Matus Rehak

Die Einreichung der Dissertation wird befürwortet.

Leipzig, den Prof. MUDr. Matus Rehak Betreuer
Prof. Dr. med. Peter Wiedemann Leiter der Einrichtung 
Gewidmet Ulli, meinen Eltern und Geschwistern (Franz, Johanna und Katharina) 


\section{INHALTSVERZEICHNIS}

Seite

1. Einführung

5

2. Publikationsmanuskript 13

3. Zusammenfassung 23

4. Literaturverzeichnis 28

5. Darstellung des eigenen Beitrages 34

6. Selbstständigkeitserklärung 35

7. Lebenslauf 36

8. Danksagung 38 


\section{Einführung}

\section{$\underline{\text { Epidemiologie und Klassifikation }}$}

Venenverschlüsse stellen eine der häufigsten Gefäßerkrankungen der Netzhaut dar (Finkelstein 1992). Es werden drei Formen unterteilt: der Zentralvenenverschluss (ZVV), der Venenastverschluss (VAV) und der Hemi-Retinale Venenverschluss (Hayreh 1994). Bei allen Formen wird zwischen einer ischämischen und einer nicht-ischämischen Variante unterschieden. Venenastverschlüsse werden differenziert in Hauptvenenast-, und makuläre Verschlüsse (Hayreh 2005; Rehak \& Wiedemann 2010).

Weltweit sind ca. 16 Millionen Menschen von einem retinalen Venenverschluss (RVV) betroffen (Rogers et al. 2010). Die Prävalenz für einen RVV liegt zwischen 0.7\% und 1.6\% (Mitchell et al. 1996). Ein VAV (Prävalenz und 5-Jahresinzidenz beträgt jeweils 0.6\%) ist häufiger als ein ZVV (Prävalenz 0.1\% und 5-Jahresinzidenz 0.2\%) (Klein et al. 2000). In der Blue Mountain Eye Studie (Mitchell et al. 1996) konnte gezeigt werden, dass es zu einem signifikanten Anstieg der Prävalenz eines RVV mit zunehmendem Alter kommt (von 0.7\% vor dem 60. Lebensjahr auf 4.6\% nach dem 80. Lebensjahr). Das Vorliegen eines RVV erhöht das kumulative Risiko ein solches Ereignis auch am Partnerauge innerhalb von fünf Jahren zu erleiden um 5\%-12\% (Hayreh et al. 1994). Risikofaktoren für einen RVV sind hohes Lebensalter, arterielle Hypertonie, Arteriosklerose, Diabetes mellitus, Hyperlipidämie, Rauchen, Glaukom, okuläre Hypertension und entzündliche Erkrankungen des Auges (wie z.B. okklusive Periphlebitis). Desweitern können eine Hyperviskosität z.B. im Rahmen einer Polyzythämie oder thrombophilen Erkrankungen (Hyperhomocysteinämie, AntiphospholipidAntikörper-Syndrom, Mangel an Antikoagulantien) zu einem RVV führen (Rehak \& Wiedemann 2010). Der betroffene Patient mit einem RVV berichtet über eine schmerzlose, progrediente Visusminderung mit einem relativen Gesichtsfeldausfall. Betroffene Personen können auch asymptomatisch sein. Funduskopisch ist das klinische Bild durch streifen- und fleckförmige intraretinale Hämorrhagien, Venendilatationen, periphere Okklusionen und einem Netzhautödem charakterisiert (Abb. 1). 


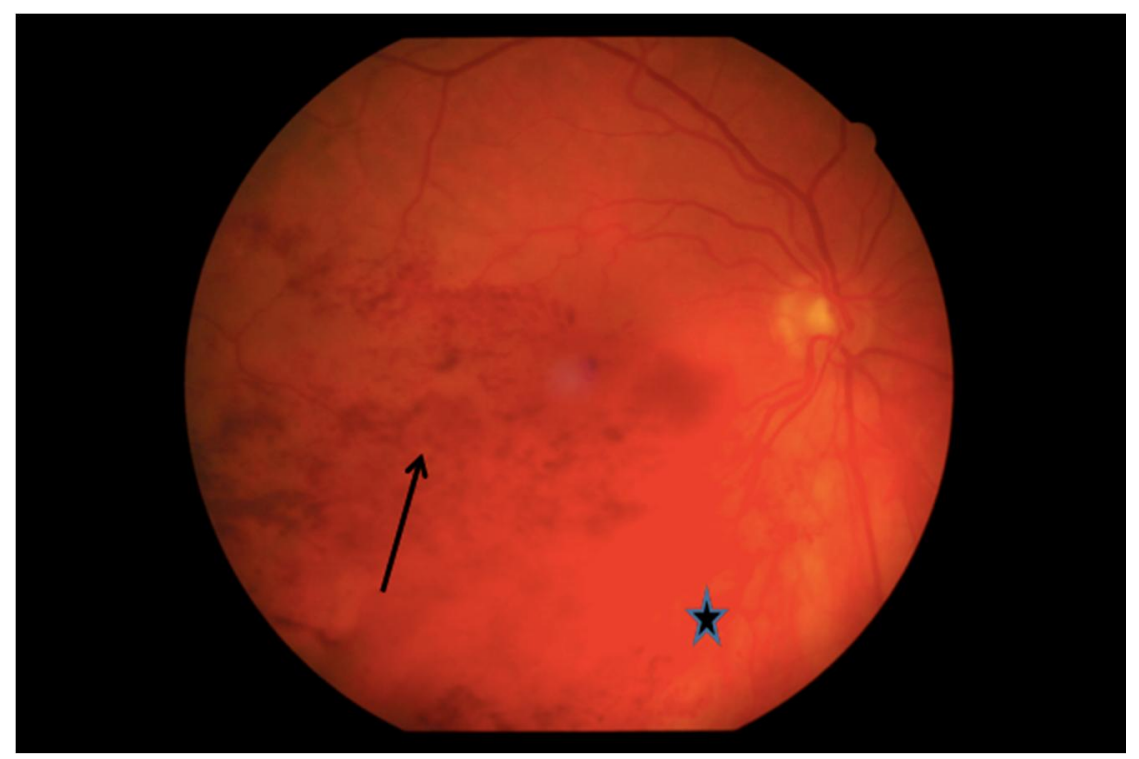

Abb. 1: Fundusfoto des rechten Auges: Venenastverschluss mit Punkt-, und Fleckblutungen im temporal unteren Quadrant (Pfeil) sowie erweiterte Venolen (Stern)

Zusätzlich kommt es bei der ischämischen Form zur Ausbildung von Cotton-Wool Herden (Abb. 2), welche Mikroinfarkte der retinalen Nervenfaserschicht darstellen (Dithmar \& Holz 2008).

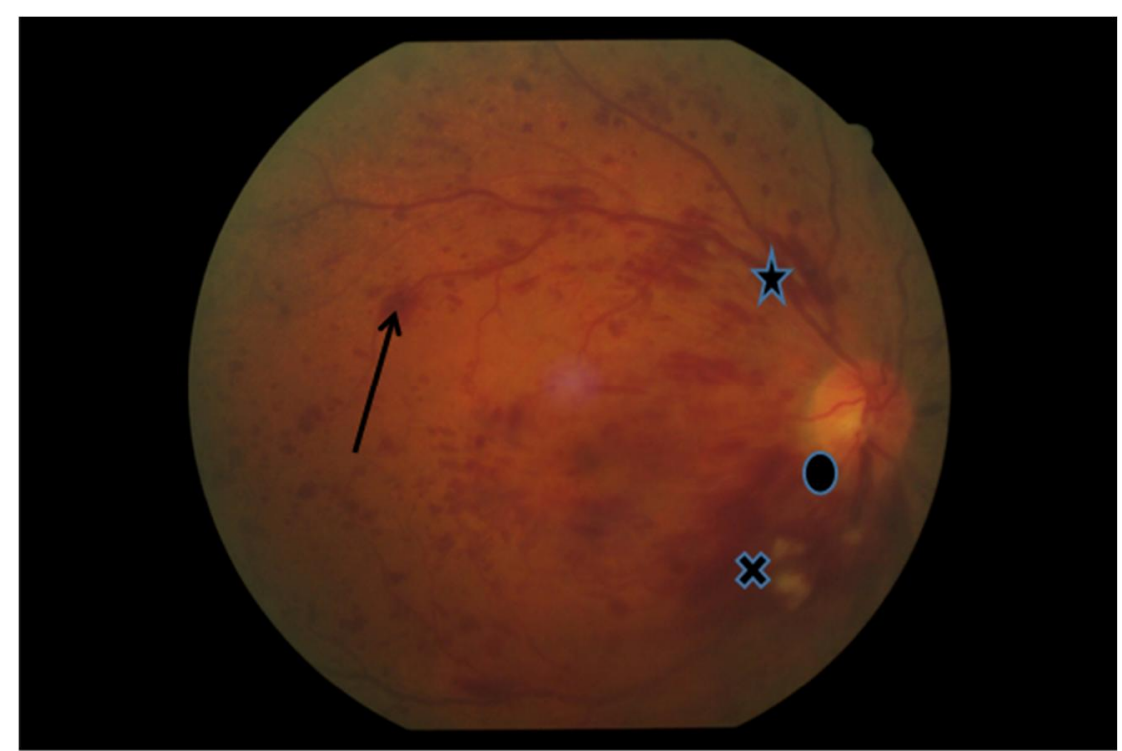

Abb. 2: Fundusfoto des rechten Auges: Zentralvenenverschluss mit Punkt-, und Fleckblutungen in allen vier Quadranten (Pfeil), erweiterte Venen (Stern), Papillenödem (Kreis) und bei 6 h ein Cotton wool Herd (Kreuz)

Zur Differenzierung einer ischämischen und nichtischämischen Form des RVV wird eine Fluoreszeinangiographie der Netzhaut durchgeführt. Ein Hauptcharackteristikum des RVV in der Fluoreszeinangiographie ist die Verbreiterung der betroffenen Vene und die verzögerte venöse Füllungsphase im Verschlussgebiet. Intraretinale Blutungen, Exsudate, Cotton-Wool 
Herde und ein Makulaödem führen zu einer Hypofluoreszenz durch eine Blockade. Eine Minderperfusion und Ischämie der Netzhaut präsentiert sich ebenfalls als Hypofluoreszenz. In der Spätphase kann es zu einer Leckage aus den Gefäßen kommen, welche sich somit als eine Hyperfluoreszenz darstellt (Dithmar \& Holz 2008).

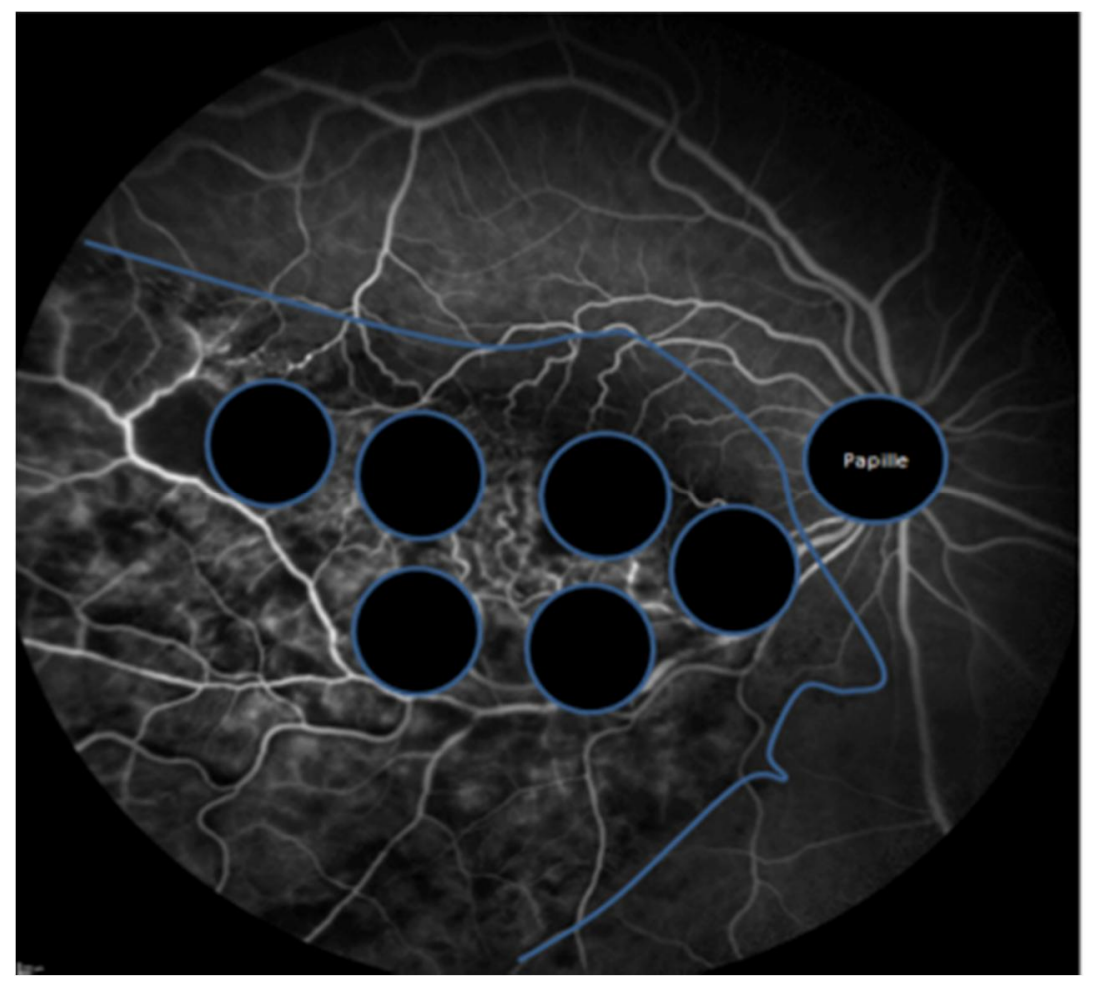

Abb. 3: Fluoreszeinangiographisches Bild des rechten Auges: Ischämischer Venenastverschluss mit mehr als 5 Papillendurchmesser große ischämische Areale

Sind bei einem ZVV mehr als 10 Papillendurchmesser ischämische Areale vorhanden, dann wird dieser als Ischämisch bezeichnet (CVOS 1993). Bei einem VAV spricht man von einer ischämischen Form, wenn die Gesamtfläche der Ischämie größer als 5 Papillendurchmesser ist (Abb.3) (BVOS 1986).

\section{Pathogenese}

Die genaue Pathogenese eines RVV ist derzeitig ungeklärt. Die Virchowsche Trias (venöse Stase, degenerative Veränderung der Gefäßwand, Bluthyperkoagulabilität) scheint eine elementare Rolle in der Entstehung eines RVV zu spielen (Yau et al. 2008). An Kreuzungsstellen besitzen die retinalen Venen und Arterien eine gemeinsame Adventitia. Beim VAV führt eine bestehende Arteriosklerose zu einer Verdickung der Arterie und somit kann es hier zu einer Lumeneinengung der Venolen kommen (Jefferies et al. 1993). 


\section{$\underline{\text { Pathogenese des Makulaödems }}$}

Entsteht ein RVV, ist dieses für die betroffenen Patienten sehr häufig mit einer Sehverschlechterung durch die Entwicklung eines Makulaödems verbunden (Rehak \& Wiedemann 2010). Unter physiologischen Bedingungen dient die Blutretinaschranke als selektive Barriere zwischen der Netzhaut und der blutzirkulierenden Netzhaut/Aderhaut (Ashton \& Cunha-Vaz 1965). Die Blutretinaschranke wird von den vaskulären Endothelzellen und den retinalen Pigmentepithelzellen (RPE-Zellen) gebildet (Finkelstein 1992; Rehák \& Rehak 2008). Faktoren die zu einem Zusammenbruch der Blutretinaschranke führen sind unter anderem Ischämie und Entzündung (Vinores et al. 1992). Ein Netzhautödem kann durch die Ansammlung von Flüssigkeit sowohl im inter-, als auch intrazellulären Raum entstehen. Das interzelluläre Netzhautödem, welches auch als extrazelluläres oder vasogenes Ödem beschrieben wird, entsteht durch eine vaskuläre Leckage durch den Zusammenbruch der Blutretinaschranke. Ein intrazelluläres Ödem (zytotoxisches Ödem) zeichnet sich durch eine Zellkompression aus und konnte beim RVV durch eine Schwellung von Neuronen und Gliazellen nachgewissen werden (Bringmann et al. 2004; Bringmann et al. 2005; Bringmann et al. 2006).

\section{Molekulare Mechanismen des interzellulären Netzhautödems beim RVV}

Für die Entwässerung und somit der Gewährleistung einer vitalen Funktion der Retina sind die retinalen Glia-, und Pigmentepithelzellen verantwortlich. Auf molekularer Ebene scheint dabei eine Kopplung von Ionen-, und Wassertransport durch Kalium-, und Chloridkanäle, als auch durch Wasserkanäle (Aquaporine, AQPs) von elementarer Bedeutung zu sein. In den retinalen Gliazellen sind die wichtigsten Kanäle für den Ionen-, und Wassertransport, der Kalium-Kanal Kir4.1 und der Wasserkanal AQP4 vorhanden (Nagelhus et al. 1999; Bringmann et al. 2004; Bringmann et al. 2006). AQP1 ist am Wassertransport aus dem subretinalen Raum durch das RPE mitbeteiligt (Stamer et al. 2003). Kommt es nun zu einer Supprimierung der Kir4.1-Kanäle, führt dies zu einer Dysregulation des transglialen Wassertransportes und somit zu einer osmotischen Schwellung der Gliazellen (Bringmann et al. 2004). In Tiermodell konnte gezeigt werden, dass Netzhauthypoxie zu einer Herabregulation der Kir4.1 und der AQP4 Protein Expression in der Netzhaut kommt (Iandiev et al. 2006a; Iandiev et al. 2007; Pannicke et al. 2004; Iandiev et al. 2006b). Dadurch entsteht eine Störung im Kalium und Wassertransport mit fehlender Resorption der intraretinalen Flüssigkeit (Bringmann et al. 2004). Diese Veränderungen wurden auch beim VAV beobachtet (Rehak et al. 2009). 


\section{Rolle des VEGF beim Makulaödem}

Eine Hyopxie stellt den maßgeblichen Faktor zur Ausschüttung des Wachstumsfaktors vascular endothelial growth factor (VEGF) dar (Adamis et al. 1993). Für VEGF wurden verschiedene Isoformen beschrieben. VEGF-A ist der wichtigste gefäßpermeabilisierende und angiogene Faktor in der Entwicklung von vasogenen Ödemen der durch Hypoxie und Entzündung im Gefäßendothel freigesetzt wird (Aiello et al. 1997; Campochiaro 2007; Zhang et al. 2009). Der Isoform VEGF-B wird das Überleben von Endothelzellen bei retinalen Neovaskularisationen zugeschrieben (Zhang et al. 2009). VEGF wird von RPE-Zellen, Perizyten, Endothel-, Glia- und Ganglienzellen gebildet (Adamis et al. 1993; Miller et. al. 1994; Robinson et. al. 2001; Eichler et al. 2000). Die Aktivität von VEGF wird von antiangiogenen Faktoren neutralisiert, vor allem durch den Pigmentepithel derived factor (PEDF) (Zhang et al. 2006).

Der Anstieg der VEGF Expression in der Netzhaut führt zur Proliferation von Netzhautendothelzellen (Aiello et al. 1995).

\section{Weitere Ursachen der Makulaödementstehung}

Eine Netzhautischämie korreliert mit einer geringgradigen Entzündung (Joussen et al. 2004; Rehak et al. 2009). Es konnte eine Erhöhung proinflammatorischer Faktoren wie z.B. Interleukin IL-1 $\beta$ und IL-6 in der Netzhaut bei dem RVV nachgewissen werden (Park \& Ahn 2008; Noma et al. 2009). Diese Faktoren steigern die Durchlässigkeit der Netzhautgefäße (Luna et al. 1997; Derevjanik et al. 2002) und sind daher auch bei der Entstehung eines Netzhautödems beteiligt (Mori et al. 2002). Dies geschieht zum Teil auch durch eine stimulierende Wirkung der VEGF-Expression (Vinores et al. 2003).

\section{Therapie des Makulaödems}

Derzeitig werden zur Behandlung des Makulaödems infolge eines Venenastverschlusses drei Therapieansätze angewendet:

1. Intavitreale Injektionen von anti-VEGF-Medikamenten

2. Applikation von Steroiden in den Glaskörperraum

3. Die fokale Laserphotokoagulation der Netzhaut

Alle drei Verfahren sind in der Lage das Makulaödem zu reduzieren und dadurch den Visus zu verbessern. 
Zum derzeitigen Zeitpunkt gibt es zur Behandlung der venösen Verschlüsse drei zugelassene intravitreale Medikamente. Es können Ranibizumab (Lucentis ${ }^{\circledR}$, Novartis, Zulassung Juni 2011), VEGF Trap Eye (Aflibercept=Eylea ${ }^{\circledR}$, Bayer HealthCare, Zulassung für ZVV September 2012 und VAV Februar 2015) und Dexamethason (OZURDEX ®, Allergan, Zulassung Juli 2010) verwendet werden. Im off-label-Verfahren wird ebenfalls Bevacizumab (Avastin $^{\circledR}$, Roche) appliziert (Feltgen et al. 2010).

\section{Anti-VEGF-Therapie des Makulaödems}

Ein Therapieansatz zur Reduktion des sekundären Makulaödems nach venösen retinalen Gefäßverschlüssen stellt die Hemmung des Wachstumsfaktors VEGF dar. Verschiedene Studien haben gezeigt, dass ein retinales Ödem bei RVV durch Gabe von anti-VEGF Medikamenten therapiert werden kann (Campochiaro et al. 2015; Cekiç et al. 2010; Rouvas et al. 2010; Hoeh et al. 2009). Derzeit werden drei Anti-VEGF Präparate zur Behandlung des Makulaödems nach RVV verwendet:

1. Bevacizumab (Avastin $\left.{ }^{\circledR}\right)$ (off-label Therapie)

2. Ranibizumab (Lucentis ${ }^{\circledR}$ )

3. Aflibercept (Eylea $\circledR)$

Bevacizumab und Ranibizumab, stellen neutralisierende Antikörper gegen den Wachstumsfaktor VEGF dar. Aflibercept ist ein humanes rekombinantes Fusionsprotein, welches die Wirkung von VEGF neutralisiert. In verschiedenen klinischen Studien konnte ein positiver Effekt der anti-VEGF Therapie sowohl auf die Reduktion des Makulaödems, als auch auf die Sehschärfe von RVV-Patienten gezeigt werden.

\section{Antientzündliche Therapie mit intravitrealen Steroiden}

Ein weiterer Ansatz zur Behandlung des Makulaödems stellen Steroide da. Zur Behandlung des Makulaödems nach RVV werden zwei Wirkstoffe aus der Gruppe der Steroide verwendet:

1. Triamcinolon (Volon $A \circledR$ oder Kenalog $\left.{ }^{\circledR}\right)$ (off-label Therapie)

2. Dexamethason (OZURDEX $®)$ (Zulassung in Europa Juli 2010)

Alle Präparate haben ein ähnliches Nebenwirkungsprofil wie sekundär induzierte Katarakt und ein Steroidglaukom. 
In der GENEVA-Studie, welche die Dexamethason Therapie beim RVV untersuchte, zeigte sich das nach zwei Implantationen die Kataraktprogression (29,8\% der phaken Augen) höher war als bei denen, die nur eine Dexamethason-Injektion erhielten. Bei 1/3 aller initial behandelten Augen stieg der Augendruck um mindestens $10 \mathrm{~mm} \mathrm{Hg}$, welcher teilweise mit drucksenkender Therapie behandelt werden mussten (Haller et al. 2010; Haller et al. 2011).

Bei der Triamcinolongabe ist neben der schlechteren Dosierbarkeit im Vergleich zu Dexamethason zusätzlich die Gefahr der Pseudoendophthalmitis gegeben (Scott al. 2009).

Dexamethason kann zur Langzeitbehandlung eingesetzt werden. Das Präparat Ozurdex ${ }^{\circledR}$ besitzt ein slow release Applikationssystem und kann somit den Wirkstoff nach der intravitrealen Applikation in den Glaskörper innerhalb von sechs Monaten durch langsames Auflösen der Matrix abgegeben. Durch den konstanten Wirkspiegel konnte gezeigt werden, dass 12 Monate nach Erstapplikation von Dexamethason es im VAV zu einer Verbesserung der Sehschärfe (im Mittel von 6 ETDRS-Buchstaben) kam, welcher der primäre Endpunkt der GENEVA-Studie war (Haller et al. 2010; Haller et al. 2011). Dies beruht vor allem auf Grund seiner stark entzündungshemmenden Wirkung (Nehme \& Edelman 2008). Ein genereller Nachteil der Behandlung sowohl mit Anti-VEGF- und Steroidpräparaten stellt die intravitreale Applikationsform dar. Bei dieser Prozedur kann es sowohl zu Verletzung der Linse als auch der Netzhaut (Netzhautforamen, Netzhautablösung, Glaskörperblutung) kommen. Bei allen intravitrealen Injektionen besteht die Gefahr einer Endophthalmitis. McCannel zeigte in einer Metaanalyse eine Endopthalmitisrate von 0,049 \% (zwischen 0,019 und 1,4\%) (McCannel 2011). Obwohl diese generell niedrig ist, existiert dennoch die Gefahr eines Verlusts des Auges, sodass alternative, risikoärmere Methoden bei VAV zur Behandlung eines CMÖ in Betracht gezogen werden sollten.

\section{Laserphotokoagulation}

Die fokale Laserphotokoagulation zur Behandlung eines Makulaödems bei VAV stellt das älteste Behandlungsverfahren dieser morphologischen Veränderung dar. In verschiedenen Studien konnte ein positiver Effekt einer Laserkoagulation auf die Sehleistung gezeigt werden (BVOS 1984; BVOS 1986). Eine zentrale, gitterförmige Laserphotokoagulation von Mikroaneurysma und den Gefäßen mit einer Leckage kann bei Patienten mit einem VAV zur Reduktion des Makulaödems eingesetzt werden.

Es müssen folgende Kriterien vorliegen: ein Visus $\leq 0,5$ und das Makulaödem muss länger als drei Monate bestehen (BVOS 1984). Interessanterweise konnte in der Central Vein Occlusion 
Study Group nach fokaler Laserphotokoagulation kein signifikanter Visusanstieg nachgewiesen werden (CVOS 1993).

Der Nachteil von diesem Verfahren sind durch den Laser induzierte Gesichtsfelddefekte und die Gefahr der späteren Ausdehnung der Lasernarben.

\section{Alternative Therapieansätze des Makulaödems: Arteriolenverengung mittels Laser}

Eine mögliche Alternative zur Behandlung eines Makulaödem bei einem VAV stellt die Arteriolenverengung (,crimping technique”) (AV) dar. Bei diesem Verfahren wird die zuführender Arterie im betroffenen Versorgungsgebiet mittels Argonlaser verengt und es kommt somit zu einer Reduktion des Blutzuflusses.

Dieses Verfahren wurde 1975 zum ersten Mal von L'Esperance beschrieben (L'Esperance, 1975). Der genaue molekulare Wirkungsmechanismus ist bisher nicht bekannt. Es wird vermutet, dass die beobachteten Effekte auf einer Reduktion des arteriellen Druckes in der durch den Venenastverschluss betroffenen Netzhautregion beruhen. Daraus resultiert ein reduzierter Blutfluss, welcher zu einer besseren Entwässerung des Makulaödems führen kann (L'Esperance, 1975; Rehak J \& Rehak M, 2008). In verschiedenen ersten klinischen Studien konnte durch Anwendung dieser Behandlungsmethode bei Patienten mit einem VAV, welcher nicht älter als 2 Monate war, eine Sehverbesserung auf 0,5 oder besser erreicht werden (Rehák J et al. 2014; Rehák J, Rehak M 2008; Erdöl und Akyol 2000).

Bis jetzt wurden keine Arbeiten publiziert, welche den Wirkungsmechanismus und das genetische Expressisonsmuster der laserinduzierten Arteriolenverengung beim VAV untersuchten. In der vorliegenden Arbeit wurde in einem Rattenmodell, bei dem ein VAV induziert wurde, die retinale Gen-Expression von VEGF und anderen Faktoren, welche in der Entstehung und Resorption eines Netzhautödems beteiligt sind, mit und ohne AV untersucht. 


\section{Publikationsmanuskript}

Köferl P., Hollborn M., Řehák J, Iandiev I., Dukic-Stefanovic S., Wiedemann P., Kohen L., Bringmann A., Rehak M. (2014) Effect of arteriolar constriction on retinal gene expression and Müller cell responses in a rat model of branch retinal vein occlusion. Graefes Arch Clin Exp Ophthalmol. 252(2):257-65. 


\title{
Effects of arteriolar constriction on retinal gene expression and Müller cell responses in a rat model of branch retinal vein occlusion
}

\author{
Patricia Köferl • Margrit Hollborn • Jiri Rehak • Ianors Iandiev • \\ Sladjana Dukic-Stefanovic • Peter Wiedemann • Leon Kohen • \\ Andreas Bringmann • Matus Rehak
}

Received: 21 May 2013 /Revised: 31 October 2013 / Accepted: 13 November 2013 / Published online: 29 November 2013

(C) Springer-Verlag Berlin Heidelberg 2013

\begin{abstract}
Background To investigate the effect of induced arteriolar constriction $(\mathrm{AC})$ on alterations in gene expression of factors implicated in the development of edema in branch retinal vein occlusion (BRVO).

Methods In Brown-Norway rats, BRVO was induced by laser photocoagulation of the veins in one half of the retina. AC of the afferent arterioles was performed $30 \mathrm{~min}$ later. We then determined the expression of Vegfa, Vegfb, Pedf, Kir4.1, Aqp4, Aqp 1, Il1 $\beta$, and Il6 with real-time polymerase chain reaction (RT-PCR) in the neuroretina and retinal pigment epithelium (RPE) after 1, 3, and 7 days. Immunostaining against GFAP, aquaporin (AQP)-4, and Kir4.1 was performed on days 1 and 3.

Results BRVO resulted in transient upregulation of Vegfa in the neuroretina on day 1 . The expressions of Kir4.1, AQP4,
\end{abstract}

P. Köferl · M. Hollborn · I. Iandiev · P. Wiedemann · L. Kohen · A. Bringmann $\cdot$ M. Rehak

Department of Ophthalmology, University of Leipzig, Leipzig, Germany

S. Dukic-Stefanovic

Paul Flechsig Institute of Brain Research, University of Leipzig, Leipzig, Germany

J. Rehak

Department of Ophtahlmology, Palacky University Olomouc, Olomouc, Czech Republic

L. Kohen

Helios Klinikum Aue, Aue, Germany

M. Rehak ( $\triangle)$

Department of Ophthalmology and Eye Hospital, Faculty of

Medicine, University of Leipzig, Liebigstrasse 10-14, 04103 Leipzig, Germany

e-mail: matus.rehak@medizin.uni-leipzig.de and AQP1 were downregulated, and $I l 1 \beta$ and $I l 6$ were strongly upregulated, on days 1 and 3 . The retinal distribution of GFAP and AQP4 proteins remained unaltered, while the Kir4.1 protein displayed redistribution from polarized to uniform retinal distribution. AC accelerated the restoration of downregulated Kir4.1, Aqp4, and Aqp1 in the RPE, of Kir4.1 in the neuroretina, and of upregulated Il6 in the neuroretina. AC did not influence the gliotic alterations of Müller cells and the redistribution of the Kir4.1 protein.

Conclusion Constriction of the afferent artery in the BRVO region accelerated the restoration of potassium channels and Il6. These alterations may contribute to faster resorption of retinal edema, and may decrease the level of inflammation.

Keywords Retinal edema $\cdot$ Gene expression $\cdot$ Branch retinal vein occlusion $\cdot$ Arteriolar constriction

\section{Introduction}

The development of macular edema is the major cause of vision loss in patients with branch retinal vein occlusion (BRVO) [1]. Both systemic and retinal factors contribute to the development of macular edema [2]. Systemic factors cause an excess influx of fluid from the vessels into the retinal parenchyma, e.g., due to an increase in hydrostatic pressure [2]. There are two retinal factors: ischemia-hypoxia and inflammation [3, 4]. Generally, retinal edema develops via vascular leakage (vasogenic edema) and/or impairment in the fluid clearance from the retinal tissue. Cases of retinal edema without angiographic vascular leakage suggest that impaired fluid clearance is an important pathogenic factor of edema [5].

The major vessel-permeabilizing factor induced by retinal hypoxia and inflammation is vascular endothelial growth 
factor (VEGF)-A [6]. Various other inflammatory factors including interleukin (IL)-1ß and IL-6 were described to be implicated in the development of macular edema [7]. Proinflammatory factors like interleukin (IL)-1ß and IL-6 are increased in retinal venous occlusive diseases. These factors increase the permeability of retinal vessels, in part by a stimulatory effect on VEGF expression, and mediate ischemic injury in the retina $[7,8]$. The expression of VEGF-A is downregulated by anti-angiogenic factors, such as pigment epithelium-derived factor (PEDF) [9, 10].

The clearance of the retinal tissue from excess fluid is suggested to be mainly mediated by an ion transport-driven water flux through retinal glial cells and the retinal pigment epithelium (RPE) [2, 5]. Müller glial cells mediate the clearance of retinal edema via a transcellular transport of potassium and water, predominantly through the inwardly rectifying potassium (Kir) channel Kir4.1 and the aquaporin-4 (AQP4) water channel $[5,11]$. The ion transport through the RPE is facilitated by various channels for sodium, potassium, chloride, and bicarbonate [11]. The water flux across the RPE is facilitated by AQP1 water channels [12]. The experimental BRVO results in rapid downregulation of Kir4.1, Aqp4, and Aqpl in the retina, a dislocation of Kir4.1 protein, and a decrease in the potassium currents of retinal glial cells [13].

Currently, intravitreal injections of steroids or anti-VEGF drugs are used to treat macular edema due to BRVO $[1,14]$. Further, grid laser photocoagulation can be performed in BRVO patients without improvement of edema after intreavitreal injections [15]. Another method, which was reported to be effective in treatment of edema due to BRVO, is laser-induced arteriolar constriction (AC), also called arterial crimping [16]. Even though some studies [17-19] showed visual improvement in BRVO patients treated by $\mathrm{AC}$, the mechanisms of the therapeutic action of this technique have not yet been clarified. AC is supposed to result in a decrease in the arterial pressure and to facilitate the draining of edema [16]. On the other hand, constriction of the arteriole that crosses the occluded area has been described to occur in situ in experimental BRVO [20], likely by a decrease in the production of vasodilating nitric oxide $[21,22]$. The constriction, which occurs within minutes and persists for several weeks, may contribute to the development of tissue hypoxia and apoptosis in the inner retina [21].

Using a rat model of BRVO in the present study, we investigated the impact of $\mathrm{AC}$ on changes in retinal gene expression of factors and channels implicated in the development/resolution of retinal edema. In addition, we determined the effects of $\mathrm{AC}$ on the alterations in the localization of water and potassium channels that may contribute to an impairment of the fluid clearance from the edematous retinal tissue. Alterations in retinal gene expression were determined in the occluded and non-occluded parts of the neuroretina and RPE.

\section{Materials and methods}

Experimental BRVO and $A C$ All procedures concerning animals were in accordance with the ARVO Statement for the Use of Animals in Ophthalmic and Vision Research, and were approved by the local authorities (Faculty of Medicine of the University of Leipzig and Landesdirektion Leipzig). All efforts were made to minimize the number of animals used and their suffering. Adult Brown-Norway rats (above $300 \mathrm{~g}$ ) were used, along with the rat model of retinal vein occlusion, as previously described $[13,23]$. The animals were reared in $12 \mathrm{~h}$ (6:00 AM -6:00 PM) light/dark cycles. The following groups were investigated: a BRVO group (32 animals) with halfretinal branch vein occlusion, and a BRVO-AC group (19 animals) with half-retinal branch vein occlusion followed by laser-induced arteriolar constriction.

Animals were anesthetized by intraperitoneal ketamine $(100 \mathrm{mg} / \mathrm{kg})$ and xylazine $(5 \mathrm{mg} / \mathrm{kg})$. In the right eye of the animals, half of the branch retinal veins near the optic nerve head were photocoagulated $15 \mathrm{~min}$ after i.p. injection of $0.2 \mathrm{ml}$ of $10 \%$ sodium fluorescein, using a blue-green argon laser with the aid of a 78-diopter lens (parameters, $1.0 \mathrm{~s}$, $50 \mu \mathrm{m}, 50-100 \mathrm{~mW}, 5-12$ spots per vein). The other half of the veins remained perfused. The contralateral eyes remained untreated and served as controls. One day after laser photocoagulation, the success of BRVO was approved by indirect stereoscopic ophthalmoscopy. In the BRVO-AC group, laser-induced constriction of the afferent arterioles of the treated half of the retina was performed $30 \mathrm{~min}$ after BRVO. To verify the stability of BRVO, fluorescein angiography with intravenous injection of $0.2 \mathrm{ml}$ of $10 \%$ sodium fluorescein was performed shortly before the animals were sacrificed with $\mathrm{CO}_{2}$ 1, 3, and 7 days after BRVO. The eyes were then enucleated; retina and RPE cells from the occluded and nonoccluded half were removed and processed separately. Reflecting the fact that the major changes in the gene expression under ischemic conditions are presented during the acute stage of BRVO [13], the retinas and RPE cells of the experimental group (with AC) were evaluated at days 1 and 3 .

Total RNA preparation and Real-time PCR Total RNA and RT-PCR were performed as previously described [24]. Briefly, total RNA was prepared from neural retinas with Trizol reagent $(0.5 \mathrm{ml}$; Gibco BRL), and from the RPE with the RNeasy Mini Kit (Qiagen, Hilden, Germany). The quality of the RNA was analyzed by agarose gel electrophoresis. After DNase treatment, cDNA was synthesized with $1 \mu \mathrm{g}$ of total RNA using the RevertAid H Minus First Strand cDNA Synthesis Kit (Fermentas, St. Leon-Roth, Germany). The cDNA was diluted by the addition of $20 \mu \mathrm{l}$ RNase-free water. Semiquantitative, real-time PCR was performed with the SingleColor Real-Time PCR Detection System (BioRad, Munich, Germany). The PCR solution contained $1 \mu \mathrm{l}$ cDNA, specific 
primer set $(0.25 \mu \mathrm{M}$ each) and $10 \mu \mathrm{l}$ of QuantiTect SYBR Green PCR Mix (Qiagen) in a final volume of $20 \mu \mathrm{l}$.

Immunostaining Isolated retinas were fixed in $4 \%$ paraformaldehyde for $2 \mathrm{~h}$. After several washing steps in buffered saline, the tissues were embedded in saline containing $3 \%$ agarose $(\mathrm{w} / \mathrm{v})$, and $80-\mu \mathrm{m}$-thick slices were cut using a vibratome. The slices were incubated in $5 \%$ normal goat serum plus $0.3 \%$ Triton $\mathrm{X}-100$ in saline for $2 \mathrm{~h}$ at room temperature and, subsequently, in primary antibodies overnight at $4{ }^{\circ} \mathrm{C}$. After washing in $1 \%$ bovine serum albumin in saline, the secondary antibodies were applied for $2 \mathrm{~h}$ at room temperature. The lack of unspecific staining was proven by negative controls, omitting the primary antibodies (not shown). The following antibodies were used: mouse antiglial fibrillary acidic protein (GFAP; 1:200; GA5 clone; Sigma-Aldrich), rabbit anti-Kir4.1 (1:200; Alomone Labs), rabbit anti-rat AQP4 (1:200; Sigma), Cy3-conjugated goat anti-rabbit IgG (1:400; Dianova), and Cy2-coupled goat antimouse IgG (1:200; Dianova). Images were recorded with a confocal laser scanning microscope (LSM 510 META; Zeiss, Oberkochen, Germany) at single planes; excitation and emission settings were held constant for all images acquired.

Data analysis The results of BRVO eyes from both animal groups (BRVO only and BRVO-AC) were compared with the levels of gene expression of the untreated control eyes. Further, the results of the animals from the BRVO-only group were compared with the BRVO-AC group. Data are expressed as mean \pm SEM. Statistical analysis was made using Prism (Graphpad Software, San Diego, CA); significance was determined by Mann-Whitney's $U$ test for two groups and the Kruskal-Wallis test followed by Dunn's comparison for multiple groups.

\section{Results}

Time-dependent alterations in the retinal gene expression after BRVO

The previous studies on retinal ischemia showed that the highest levels of gene changes could be observed $24 \mathrm{~h}$ after the induction of the ischemia [13,24]. Therefore, we sought to determine BRVO-induced alterations in the mRNA levels of factors implicated in neuroretina and RPE edema development/resolution after 1, 3, and 7 days of BRVO, both in the occluded and non-occluded parts of the tissues. Representative images of PCR products analyzed by agarose gel electrophoresis for Vegfa, Vegfb, Pedf, Il1ß, Il6, Kir4.1, Aqp1, and Aqp4 are shown in Fig. 1.

$V e g f a, V e g f b$, Pedf The induction of BRVO resulted in a biphasic regulation of Vegfa in the neuroretina (Fig. 2), with an early increase after 1 day of BRVO followed by a transient decrease after 3 days. The transient upregulation of Vegfa was observed in the occluded, but not in the non-occluded part of the neuroretina. In the RPE, no alteration in the expression level of Vegfa was observed, with the exception of a slight upregulation after 3 days of BRVO (Fig. 2). Vegfb expression remained unchanged after BRVO in the neuroretina (Fig. 2). In the RPE, the expression level of $V e g f b$ significantly decreased after 3 and 7 days of BRVO (Fig. 2). The expression level of Pedf displayed a time-dependent increase in the neuroretina after 3 days of BRVO. In the RPE, a slight downregulation of Pedf was found after 1 day of BRVO (Fig. 2).

Kir4.1, Aqp4, Aqp1 BRVO induced a rapid decrease in the gene expression levels of the potassium channel Kir4.1, and of
Fig. 1 Representative images of PCR products analyzed by agarose gel electrophoresis. Amplicons for Vegfa, Vegfb, Pedf, I11ß, I16, Kir4.1, Aqp1, and Aqp4 using cDNA from retinas (R1, R2) and RPE-cells (RPE1, RPE2) of untreated rats are shown. The expression was investigated with real-time PCR The negative controls (NTC) were done by adding doubledistilled water instead of cDNA as template. Actb, $\beta$-actin, was used as a housekeeping gene
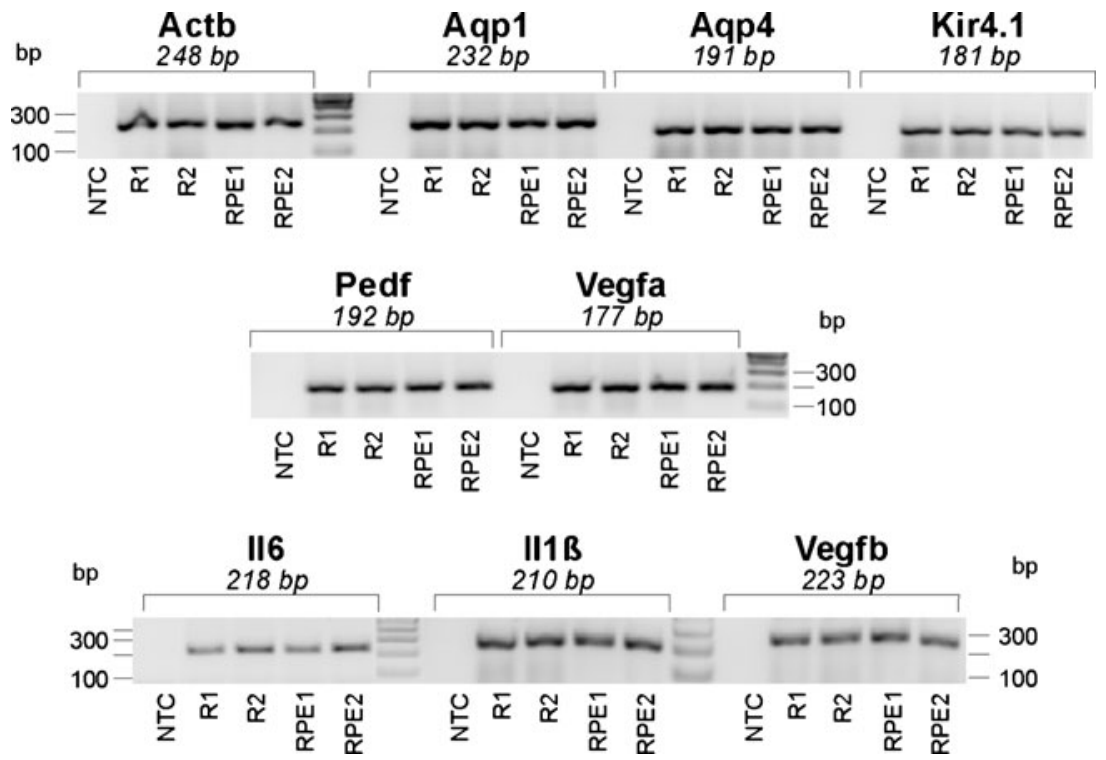
the water channels AQP4 and AQP1, in both the neuroretina and RPE (Fig. 3). The downregulation of Kir4.1, Aqp4, and Aqpl was observed in the occluded and non-occluded parts of the retina (Fig. 3). In the neuroretina, the expression of Kir4.1 returned to control levels within 7 days, while the expression of Aqp1 and Aqp4 remained decreased as compared to the controls (Fig. 3). In the RPE, there was a conspicuous, transient upregulation of Kir4.1 and Aqp4 after 7 days of BRVO (Fig. 3).

$I l 1 \beta$, Il6 Experimental BRVO was associated with increases in the relative expression levels of $I l 1 \beta$ and $I l 6$ in the neuroretina (Fig. 4). Within 1 day of BRVO, the expression of $I l 1 \beta$ and $I l 6$ increased to levels 40 - and 80-times higher than controls, respectively. In the RPE, Il6 was upregulated immediately after the induction of BRVO, and both $I l 1 \beta$ and Il6 were significantly downregulated after 7 days of BRVO (Fig. 4).
Effect of AC on BRVO-induced alterations in retinal gene expression

AC, carried out 30 min after BRVO, prevented the downregulation of $\operatorname{Veg} f b$ (Fig. 2), and accelerated the restoration of downregulated Kir4.1, Aqp4, and Aqp1 in the RPE, and of Kir4. 1 in the neuroretina, after 3 days of BRVO (Fig. 3). In addition, AC was associated with a faster decrease in the upregulated level of $I l 6$ in the neuroretina after 3 days of BRVO (Fig. 4).

\section{GFAP immunoreactivity}

Retinal gliosis is characterized by an increase in the immunoreactivity of GFAP in Müller cells [25]. However, as described recently [13], BRVO is not accompanied by a broad increase
Fig. 2 Effects of arteriolar constriction (AC) on the BRVOinduced alterations in the relative expression levels of $V e g f a, V e g f b$, and $P e d f$ in the neural retina (left) and RPE (right). The gene expression levels were determined in the occluded and non-occluded parts of the BRVO retinas (right eyes) with real-time PCR after 1, 3, and 7 days of BRVO; they are expressed in relation to the values obtained in tissues from untreated control (left) eyes, which are displayed as levels of 1 (gray background area). Each bar represents the mean obtained in tissues from 7 to 10 animals; error bars represent S.E.M. Significant difference vs. untreated control: $* P<0.05$; $* * P<0.01 ; * * * P<0.001$.

Significant difference between BRVO and BRVO-AC:

${ }^{+} P<0.01$. Significant difference between occluded and nonoccluded parts of the BRVO retina: ${ }^{\circ} P<0.05 ;{ }^{\circ} P<0.01$

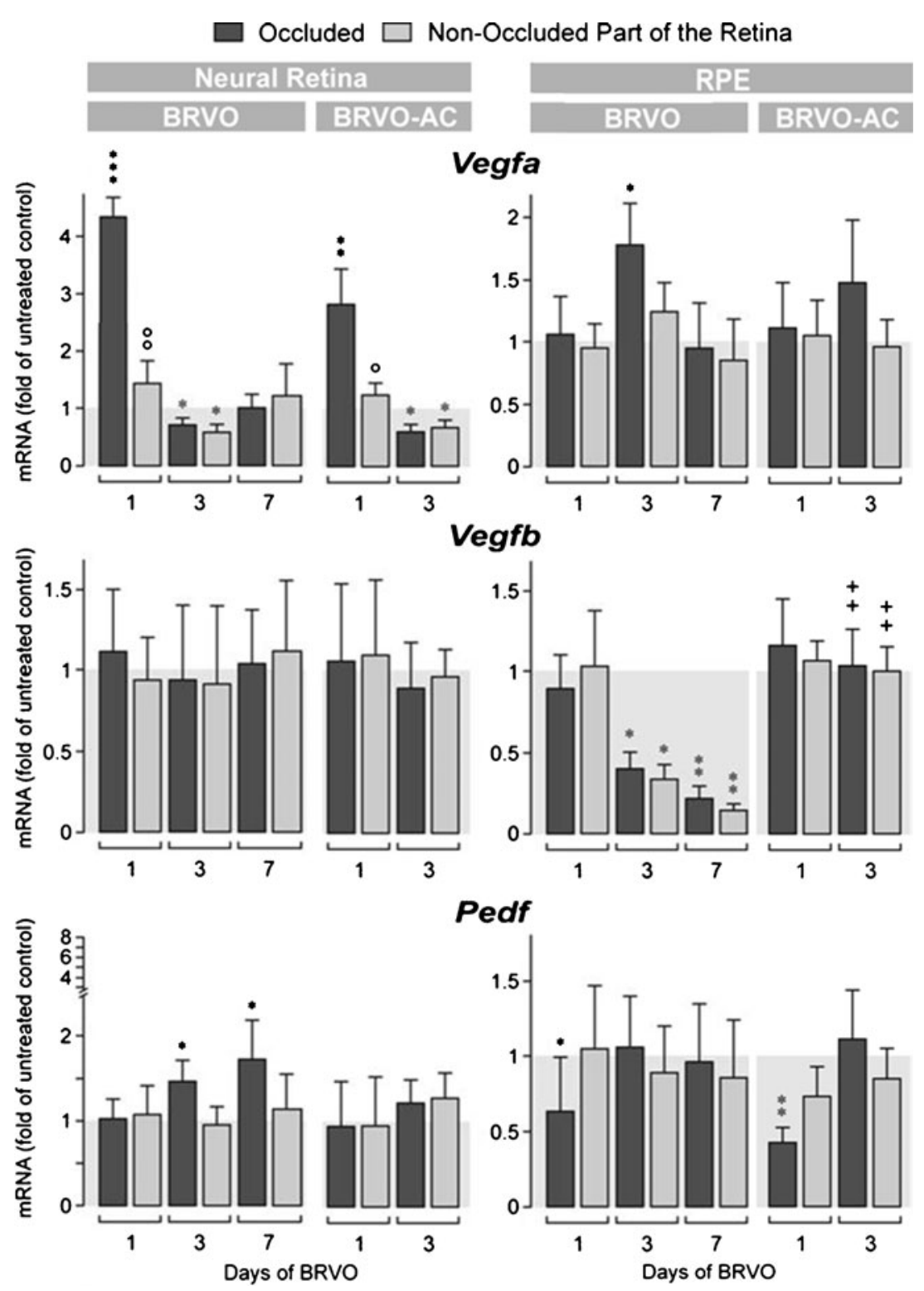


Fig. 3 Effects of arteriolar constriction (AC) on the BRVOinduced alterations in the relative expression levels of Kir4.1, Aqp4, and Aqp1 in the neural retina (left) and RPE (right). The gene expression levels were determined in the occluded and non-occluded parts of the BRVO retinas (right eyes) with real-time PCR after 1, 3, and 7 days of $\mathrm{BRVO}$, and are expressed in relation to the values obtained in tissues from untreated control (left) eyes, which are displayed as levels of 1 (gray background area). Each bar represents the mean obtained in tissues from 7 to 10 animals; error bars represent S.E.M. Significant difference vs. untreated control: $* P<0.05$; $* * P<0.01 ; * * * P<0.001$. Significant difference between BRVO and BRVO-AC: ${ }^{+} P<0.05$; ${ }^{++} P<0.01$. Significant difference between occluded and nonoccluded parts of the BRVO retina: ${ }^{\circ} P<0.05$

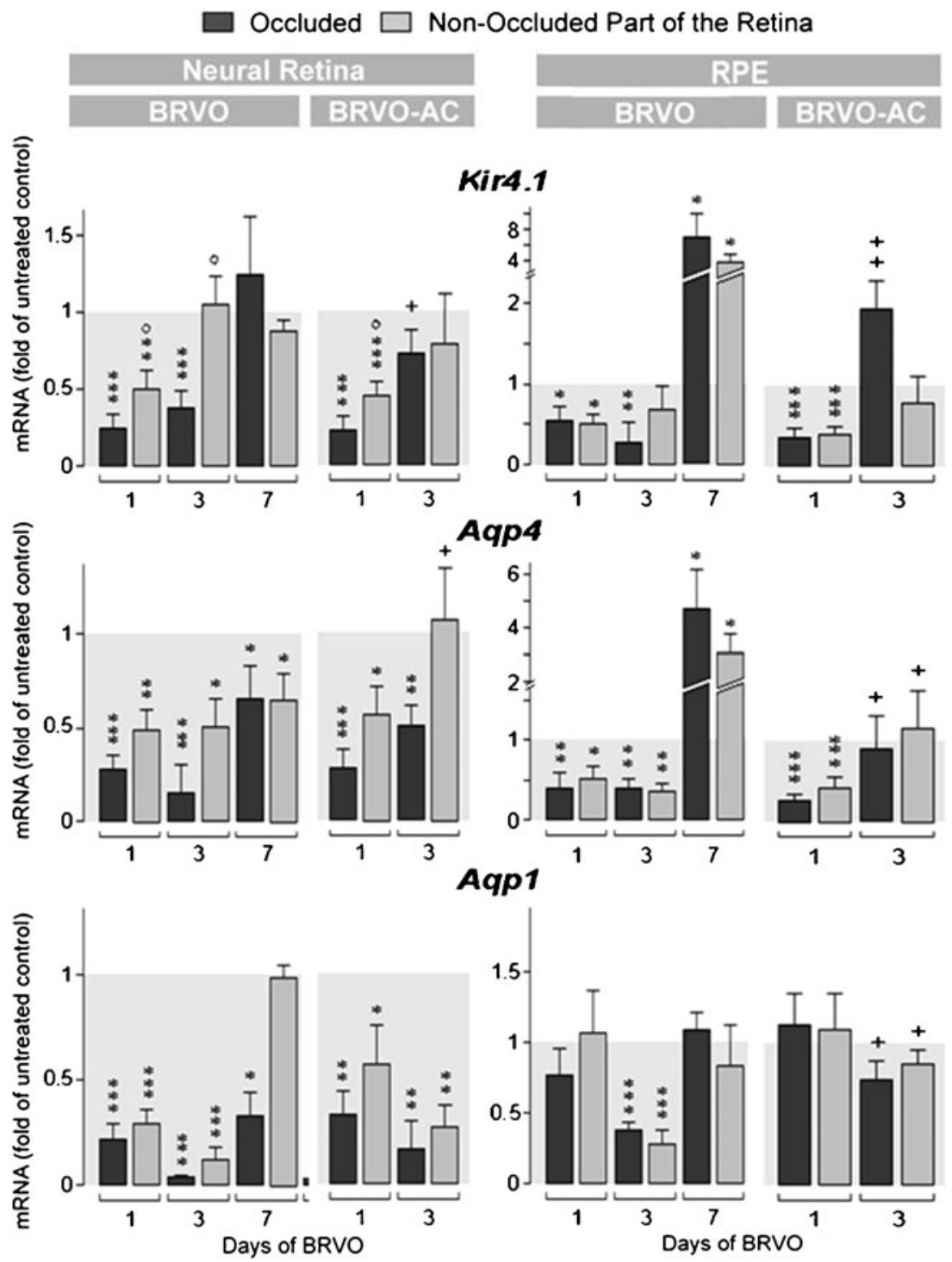

in GFAP in Müller cells. This fact was confirmed in the present study. In control retinal slices, GFAP immunoreactivity was localized to astrocytes in the nerve fiber layer (Fig. 5). In retinal slices obtained 3 days after BRVO, the distribution of GFAP immunoreactivity remained largely unaltered, with the exception of some vessels, which traverse the inner plexiform layer, and which were surrounded by GFAP-expressing cell structures (Fig. 5). This pattern of GFAP distribution was observed in slices of BRVO and BRVO-AC retinas, both in the occluded (Fig. 5) and non-occluded (not shown) areas of the retinas, and also in retinal slices obtained after 1 day of BRVO (not shown).

\section{AQP4 immunoreactivity}

The glial water channel AQP4 is predominantly localized to the inner retina and outer plexiform layer (Fig. 5). In addition to the perisynaptic localization in both plexiform layers,
AQP4 immunoreactivity is enriched in perivascular spaces (Fig. 5). The overall retinal distribution of AQP4 labeling remained largely unaltered after BRVO and BRVO-AC, with the exception of sites of cystoid tissue degeneration that disrupted the regular structure of the inner nuclear and outer plexiform layers (asterisks in Fig. 5). Cystoid degeneration of the tissue, which reflects sites of retinal edema, was found in many but not all slices of BRVO and BRVO-AC retinas.

\section{Kir4.1 immunoreactivity}

Kir4.1 is the major potassium channel of Müller cells [26]. It has been shown that experimental BRVO leads to a redistribution of the Kir4.1 protein in the retinal tissue within 3 days [13]. This fact was confirmed in the present study. In control retinal tissues, immunoreactive Kir4.1 protein displayed a polarized distribution with prominent localization in the innermost retinal layers (nerve fiber and ganglion cell layers) 
Fig. 4 Effects of arteriolar constriction (AC) on the BRVOinduced alterations in the relative expression levels of $I l 1 \beta$ and $I l 6$ in the neural retina (left) and RPE (right). The gene expression levels were determined in the occluded and non-occluded parts of the BRVO retinas (right eyes) with real-time PCR after 1, 3, and 7 days of BRVO, and are expressed in relation to the values obtained in tissues from untreated control (left) eyes, which are displayed as levels of 1 (gray background area). Each bar represents the mean obtained in tissues from 7 to 10 animals; error bars represent S.E.M. Significant difference vs. untreated control: $* P<0.05 ; * * P<0.01$;

$* * * P<0.001$. Significant difference between BRVO and BRVO-AC: ${ }^{+} P<0.05$

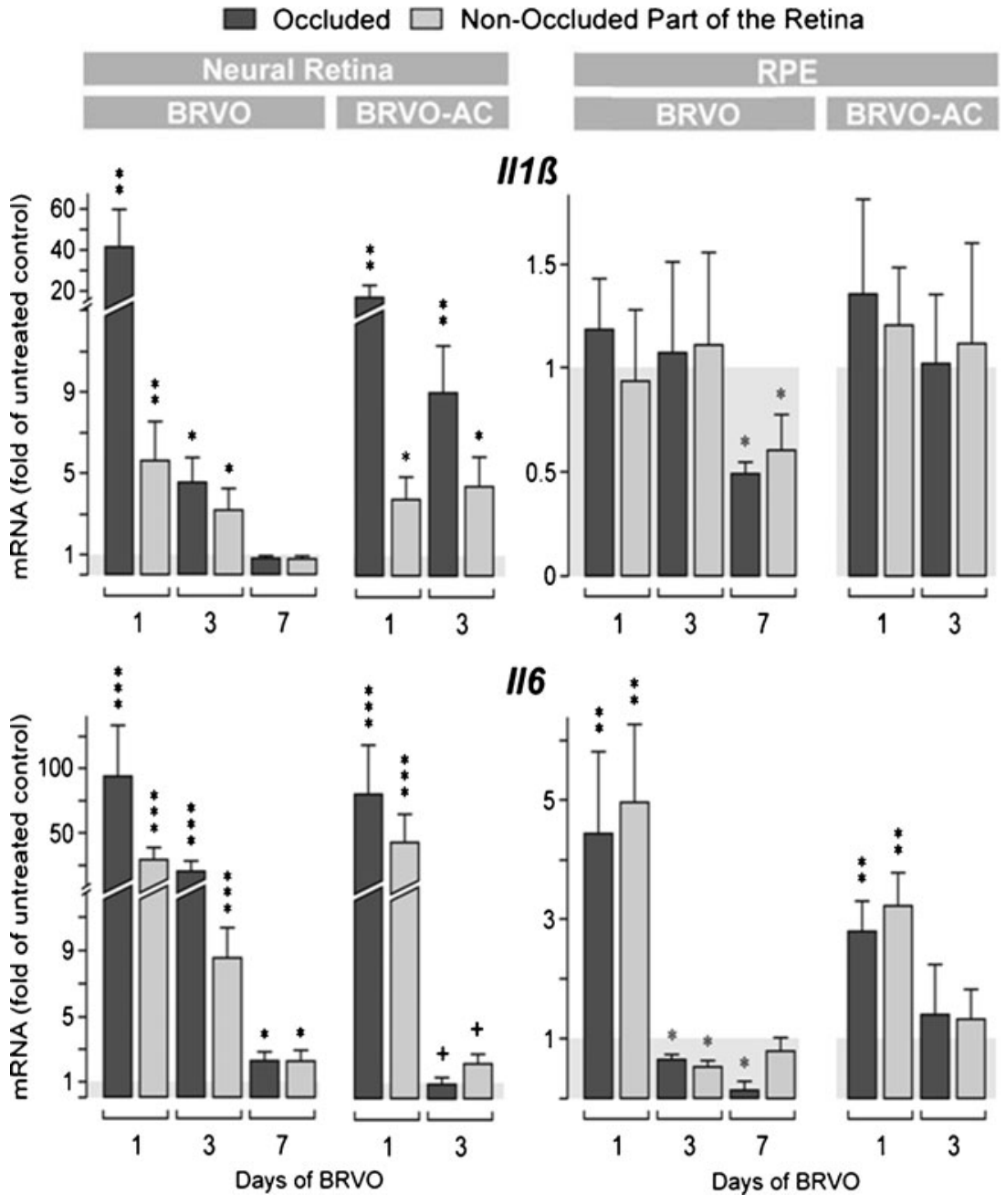

and around the blood vessels, whereas the staining of the remaining tissue was faint (Fig. 6). This polarized distribution was lost within 3 days of BRVO, and the Kir4.1 immunoreactivity displayed a rather uniform distribution within the retinal tissue (Fig. 6). A similar redistribution of Kir4.1 immunolabeling was observed in BRVO retinas treated with
AC (Fig. 6). The redistribution of the Kir4.1 protein was a time-dependent process; the disappearance of perivascular Kir4.1 occurred between 1 and 3 days of BRVO (Fig. 6). Apparently, the redistribution of the Kir4.1 protein proceeded from the innermost to the more outer parts of the retina. In contrast to the occluded parts of the BRVO retinas, a distinct
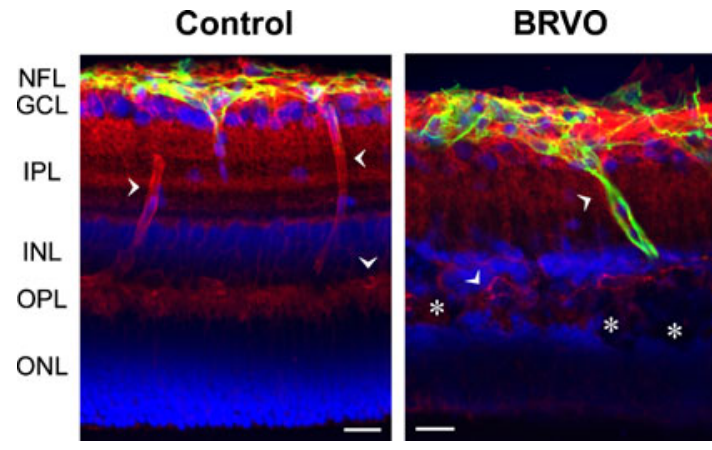

BRVO-AC

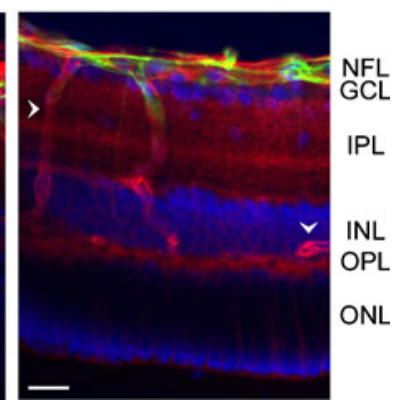

Fig. 5 Immunolocalization of the glial intermediate filament GFAP (green) and the glial water channel AQP4 (red) in slices of a control retina and of retinas obtained after 3 days of BRVO and BRVO-AC, respectively. Double labeling yielded a yellow staining. The BRVO tissues were obtained from the occluded parts of the retinas. Cell nuclei were labeled with Hoechst 33258 (blue). Arrowheads, blood vessels. Asterisks, cystoid spaces. GCL, ganglion cell layer; INL, inner nuclear layer; IPL, inner plexiform layer; NFL, nerve fiber layer; ONL, outer nuclear layer; OPL, outer plexiform layer. Bars, $20 \mu \mathrm{m}$ 


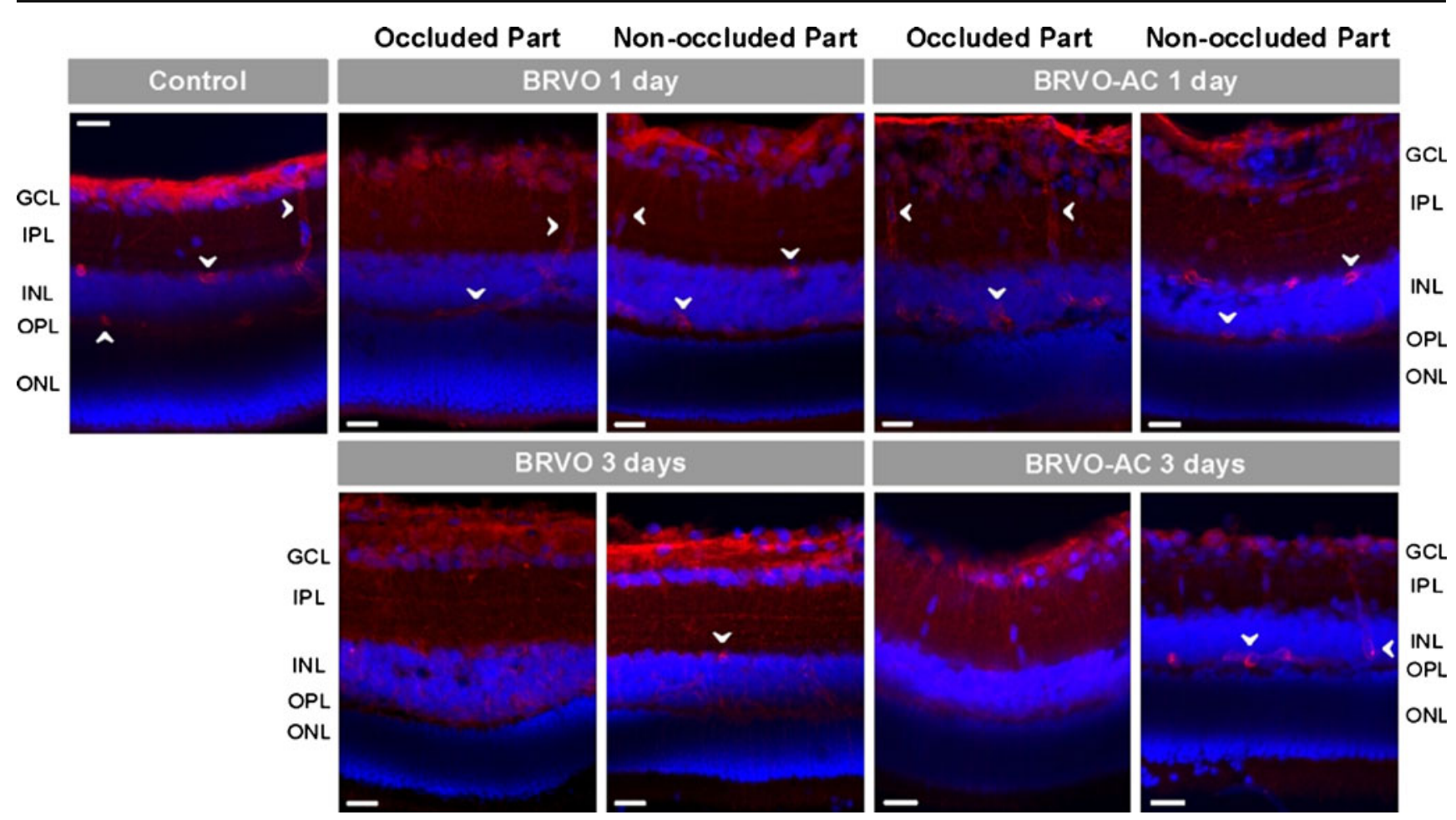

Fig. 6 Immunolocalization of the glial potassium channel Kir4.1 (red) in slices of a control retina and of retinas obtained after 1 and 3 days, respectively, of BRVO and BRVO-AC. The BRVO tissues were obtained from the occluded and non-occluded parts of the retinas. Cell nuclei were labeled with Hoechst 33258 (blue). In the control tissue, the Kir4.1 protein is concentrated in the innermost retinal layer and around the blood

degree of perivascular Kir4.1 staining remained apparent for up to 3 days in the non-occluded parts of BRVO retinas, both in AC-treated and non-treated tissues (Fig. 6).

\section{Discussion}

In a rat model of BRVO, we investigated the effects of $\mathrm{AC}$ on the alterations in the gene expression of factors implicated in the development and resolution of retinal edema. We found that BRVO-induced alterations in gene expression were rather complex, and differed depending on the tissue investigated (neuroretina and RPE), and on the duration of BRVO-induced retinal ischemia. Distinct alterations in gene expression were restricted to the occluded part of the neuroretina (e.g., the upregulation of Vegfa after 1 day of BRVO; Fig. 2) whereas other alterations were observed in both the occluded and nonoccluded parts of the neuroretina (e.g., the downregulation of Kir4.1, Aqp4, and Aqp 1; Fig. 3). Other alterations were found only in the neuroretina (e.g., the upregulation of $I l 1 \beta$; Fig. 4) or RPE (e.g., the downregulation of Vegfb; Fig. 2).

There are some conspicuous alterations in the retinal gene expression in response to BRVO, including: (1) a biphasic regulation of Vegfa in the occluded part of the neuroretina, with upregulation after 1 day and downregulation after 3 days vessels (arrowheads). This polarized localization was lost within 3 days of BRVO. In the tissues from the non-occluded parts of the retina, some perivascular staining remained apparent up to 3 days of BRVO (arrowheads). GCL, ganglion cell layer; INL, inner nuclear layer; IPL, inner plexiform layer; ONL, outer nuclear layer; OPL, outer plexiform layer. Bars, $20 \mu \mathrm{m}$

of BRVO (Fig. 2); (2) a time-dependent upregulation of Pedf in the neuroretina (Fig. 2); (3) a transient downregulation of the potassium and water channels Kir4.1, Aqp4, and Aqp1 in the neuroretina and RPE (Fig. 3); and (4) strong, timedependent upregulation of $I l 1 \beta$ and Il6 in the neuroretina (Fig. 4). The rapid upregulation of Vegfa in the occluded retina (Fig. 2) suggests that BRVO results in tissue hypoxia selectively in the neuroretina of the treated half of the retinal tissue. Thus, the alterations in retinal gene expression observed in the RPE and in the non-occluded part of the retina are likely a response to the laser-induced hypoxia within the occluded part of the neuroretina.

Gene expression alterations in both the occluded and nonoccluded retinal areas of eyes with BRVO may underlie the Müller cell gliosis observed in both parts of the retina. With respect to AQP4, we found a downregulation of Aqp4 (Fig. 3) but no apparent dislocation of the AQP4 protein in the retina (Fig. 5). Similar results (dislocation of Kir4.1 protein but not of AQP4 protein) were previously described in a rat model of high intraocular pressure-induced retinal ischemia-reperfusion [27]. In our previous experiments, we described that BRVO is associated with Müller cell swelling under hypoosmotic stress, which is not observed in Müller cells from control tissues, [13] suggesting that BRVO induces a disturbance of the osmotically-induced, transglial water flux. The 
downregulation of Kir4.1 and aquaporins, and the dislocation of the Kir4.1 protein may contribute to the development of tissue edema, and (via disturbance of the retinal potassium homeostasis) to neuronal degeneration.

Gene expression of Kir4.1 and aquaporin-4 and the membrane anchoring of Kir4.1 are sensitive to retinal ischemia, whereas the membrane anchoring of aquaporin- 4 is insensitive to ischemia. Based on observations in knockout mice, it has been suggested that $\alpha$-syntrophin (a protein of the dystrophin-associated protein complex) is implicated in the membrane anchoring of aquaporin-4 but not of Kir4.1 [28]. Similar mislocation of the Kir4.1 protein and unaltered retinal distribution of the aquaporin-4 protein were described in animal models of retinal ischemia-reperfusion, retinal detachment, and diabetic retinopathy $[29,30]$. The mechanism of the ischemia-sensitive membrane anchoring of Kir4.1 remains to be determined.

We found a rapid upregulation of the proinflammatory factors VEGF-A (Fig. 2), IL-1ß, and IL-6 (Fig. 4) after induction of BRVO. Though these factors may induce a response cascade in the retina that finally results in inflammatory tissue degeneration and edema development, all of these factors were described to have also protective effects in the neural tissue, including the retina. IL-6 is a cytokine with pleiotropic functions. It is a mediating protein during inflammation processes and the maturation of $\mathrm{B}$ cells. The protein is primarily produced at sites of inflammation and induces a transcriptional inflammatory response through IL-6 receptor-alpha, which is associated with VEGF expression [31]. VEGF-A supports the survival of endothelial cells and retinal neurons. IL-6 is protective for retinal ganglion cells and photoreceptors [27, 32], and IL-1 promotes the glutamate uptake into Müller cells and the survival of retinal ganglion cells and photoreceptors [33]. It cannot be ruled out that the decrease in the upregulation of these factors observed after 3 and 7 days of BRVO might contribute to ischemic tissue degeneration.

The aim of the present study was to investigate the effect of laser-induced AC on BRVO-induced alterations in the retinal gene expression and the retinal localization of glial potassium and water channels. AC was first described by L'Esperance [16] in 1975. Several clinical studies [17-19] reported the resolution of macular edema and improvement of visual acuity in patients with BRVO treated with AC, but the mechanisms of the therapeutic action remain unclear. It was suggested that $\mathrm{AC}$ results in a decrease in the hydrostatic pressure within the arterioles and capillaries of the occluded vascular bed [16]. A decrease in the hydrostatic pressure will lower the water flux from the vessels into the tissue and, thus, may inhibit the development of vasogenic edema [2]. It has been described that an increase in hydrostatic pressure (hypertension) aggravates retinal inflammation [34]. Thus, through a decrease in hydrostatic pressure, AC might be also protective against retinal inflammation. On the other hand, constriction of the afferent artery was described to occur in experimental BRVO [20]. Some authors suggest that this constriction contributes to the development of tissue hypoxia $[21,22]$. Therefore, laser-induced AC has not been generally accepted as a technique for the treatment of macular edema in patients with BRVO.

In our experiments, we found that $\mathrm{AC}$ did not prevent the redistribution of the Kir4.1 protein in the retina (Fig. 6). On the other hand, our results did not show any worsening of retinal ischemia after AC. Distinct effects of AC on the retinal gene expression might be protective against the development of retinal edema. The acceleration of the restoration of downregulated Kir4.1, Aqp4, and Aqp1 in the RPE (Fig. 3), and of Kir4.1 in the neuroretina (Fig. 3), may contribute to a faster resolution of retinal edema, while accelerated restoration of the upregulated level of Il6 in the neuroretina (Fig. 4) may limit retinal inflammation and, thus, the extent of vessel permeabilization. All effects of AC on the retinal gene expression were observed after 3 days, but not after 1 day of BRVO. It is concluded that $\mathrm{AC}$ has delayed effects on retinal gene expression and Müller cell properties. It remains to be determined whether a decrease in hydrostatic pressure is a causative factor of the AC-induced acceleration in the decrease of upregulated Il6 (Fig. 4).

Acknowledgments This study was supported by grants from the Deutsche Forschungsgemeinschaft (KO 1547/6-1, GRK 1097/1). The authors wish to thank Ute Weinbrecht and Franziska Rickers for excellent technical assistance.

Conflict of interest The authors declare that they have no conflict of interests to disclose. The authors have full control of all primary data and they agree to allow Graefes Archive for Clinical and Experimental Ophthalmology to review their data upon request.

\section{References}

1. Rehak M, Wiedemann P (2010) Retinal vein thrombosis: pathogenesis and management. J Thromb Haemost 8:1886-1894

2. Bringmann A, Pannicke T, Grosche J, Francke M, Wiedemann P, Skatchkov SN, Osborne NN, Reichenbach A (2006) Müller cells in the healthy and diseased retina. Prog Retin Eye Res 25:397-424

3. Tso MOM (1982) Pathology of cystoid macular edema. Ophthalmology 89:902-915

4. Marmor MF (1999) Mechanisms of fluid accumulation in retinal edema. Doc Ophthalmol 97:239-249

5. Bringmann A, Reichenbach A, Wiedemann P (2004) Pathomechanisms of cystoid macular edema. Ophthalmic Res 36: 241-249

6. Aiello LP, Bursell SE, Clermont A, Duh E, Ishii H, Takagi C, Mori F, Ciulla TA, Ways K, Jirousek M, Smith LE, King GL (1997) Vascular endothelial growth factor-induced retinal permeability is mediated by protein kinase $C$ in vivo and suppressed by an orally effective $\beta$ isoform-selective inhibitor. Diabetes 46:1473-1480

7. Derevjanik NL, Vinores SA, Xiao WH, Mori K, Turon T, Hudish T, Dong S, Campochiaro PA (2002) Quantitative assessment of the 
integrity of the blood-retinal barrier in mice. Invest Ophthalmol Vis Sci 43:2462-2467

8. Bastiaans J, van Meurs JC, van Holten-Neelen C, Nijenhuis MS, Kolijn-Couwenberg MJ, van Hagen PM, Kuijpers RW, Hooijkaas H, Dik WA (2013) Factor Xa and thrombin stimulate proinflammatory and profibrotic mediator production by retinal pigment epithelial cells: a role in vitreoretinal disorders? Graefes Arch Clin Exp Ophthalmol 251:1723-1733

9. Zhang SX, Wang JJ, Gao G, Parke K, Ma JX (2006) Pigment epithelium-derived factor downregulates vascular endothelial growth factor (VEGF) expression and inhibits VEGF-VEGF receptor 2 binding in diabetic retinopathy. $\mathrm{J}$ Mol Endocrinol 37:1-12

10. Noma H, Funatsu H, Mimura T, Harino S, Eguchi S, Hori S (2010) Pigment epithelium-derived factor and vascular endothelial growth factor in branch retinal vein occlusion with macular edema. Graefes Arch Clin Exp Ophthalmol 248:1559-1565

11. Wimmers S, Karl MO, Strauss O (2007) Ion channels in the RPE. Prog Retin Eye Res 26:263-301

12. Stamer WD, Bok D, Hu J, Jaffe GJ, McKay BS (2003) Aquaporin-1 channels in human retinal pigment epithelium: role in transepithelial water movement. Invest Ophthalmol Vis Sci 44:2803-2808

13. Rehak M, Hollborn M, Iandiev I (2009) Retinal gene expression and Müller cell responses after branch retinal vein occlusion in the rat. Invest Ophthalmol Vis Sci 50:2359-2367

14. Ramezani A, Esfandiari H, Entezari M, Moradian S, Soheilian M, Dehsarvi B, Yaseri M (2012) Three intravitreal bevacizumab versus two intravitreal triamcinolone injections in recent-onset branch retinal vein occlusion. Graefes Arch Clin Exp Ophthalmol 250:1149-1160

15. Anon (1984) Branch vein occlusion study group. Argon laser photocoagulation for macular edema in branch vein occlusion. Am J Ophthalmol 98:271-282

16. L'Esperance F (1975) Ocular Photocoagulation. A Stereoscopic Atlas. St. Louis, CV Mosby, pp 215-222

17. Jalkh AE, Avila PM, Zakka KA, Trempe CL, Schepens CS (1984) Chronic macular edema in retinal branch vein occlusion: role of laser photocoagulation. Annals Ophthalmol 16:526-533

18. Rehak J, Dusek L, Sin M, Babkova B, Pracharova Z, Rehak M (2013) Long-term visual outcome after arteriolar constriction in patients with branch retinal vein occlusion. Biomed Pap Med Fac Univ Palacky Olomouc Czech Repub. doi:10.5507/bp.2013.008. Epub 2013 Feb 18

19. Erdol H, Akyol N (2000) Arterial crimping in branch retinal vein occlusion with macular edema. Acta Ophthalmol Scand 78:456-459

20. Kohner EM, Dollery CT, Shakib M, Henkind P, Paterson JW, De Oliveira LN, Bulpitt CJ (1970) Experimental retinal branch vein occlusion. Am J Ophthalmol 69:778-825

21. Donati G, Pournaras CJ, Pizzolato GP, Tsacopoulos M (1997) Decreased nitric oxide production accounts for secondary arteriolar constriction after retinal branch vein occlusion. Invest Ophthalmol Vis Sci 38:1450-1457
22. Pournaras CJ, Rungger-Brändle E, Riva CE, Hardarson SH, Stefánsson E (2008) Regulation of retinal blood flow in health and disease. Prog Retin Eye Res 27:284-330

23. Saito Y, Park L, Skolik SA, Alfaro DV, Chaudhry NA, Barnstable CJ, Liggett PE (1997) Experimental preretinal neovascularization by laser-induced venous thrombosis in rats. Curr Eye Res 16:26-33

24. Rehak M, Drechsler F, Köferl P, Hollborn M, Wiedemann P, Bringmann A, Kohen L (2011) Effects of intravitreal triamcinolone acetonide on retinal gene expression in a rat model of central retinal vein occlusion. Graefes Arch Clin Exp Ophthalmol 249:1175-1183

25. Bringmann A, Iandiev I, Pannicke T, Wurm A, Hollborn M, Wiedemann P, Osborne NN, Reichenbach A (2009) Cellular signaling and factors involved in Müller cell gliosis: neuroprotective and detrimental effects. Prog Retin Eye Res 28:423-451

26. Kofuji P, Ceelen P, Zahs KR, Surbeck LW, Lester HA, Newman EA (2000) Genetic inactivation of an inwardly rectifying potassium channel (Kir4.1 subunit) in mice: phenotypic impact in retina. J Neurosci 20:5733-5740

27. Sanchez RN, Chan CK, Garg S, Kwong JM, Wong MJ, Sadun AA, Lam TT (2003) Interleukin-6 in retinal ischemia reperfusion injury in rats. Invest Ophthalmol Vis Sci 44:4006-4011

28. Puwarawuttipanit W, Bragg AD, Frydenlund DS, Mylonakou MN, Nagelhus EA, Peters MF, Kotchabhakdi N, Adams ME, Froehner SC, Haug FM, Ottersen OP, Amiry-Moghaddam M (2006) Differential effect of alpha-syntrophin knockout on aquaporin-4 and Kir4.1 expression in retinal macroglial cells in mice. Neuroscience 137:165-175

29. Pannicke T, Iandiev I, Uckermann O, Biedermann B, Kutzera F, Wiedemann P, Wolburg H, Reichenbach A, Bringmann A (2004) A potassium channel-linked mechanism of glial cell swelling in the postischemic retina. Mol Cell Neurosci 26: 493-502

30. Iandiev I, Uckermann O, Pannicke T, Wurm A, Tenckhoff S, Pietsch UC, Reichenbach A, Wiedemann P, Bringmann A, Uhlmann S (2006) Glial cell reactivity in a porcine model of retinal detachment. Invest Ophthalmol Vis Sci 47:2161-2171

31. Cohen T, Nahari D, Cerem LW, Neufeld G, Levin BZ (1996) Interleukin 6 induces the expression of vascular endothelial growth factor. J Biol Chem 271(2):736-741

32. Chong DY, Boehlke CS, Zheng QD, Zhang L, Han Y, Zacks DN (2008) Interleukin-6 as a photoreceptor neuroprotectant in an experimental model of retinal detachment. Invest Ophthalmol Vis Sci 49: 3193-3200

33. Namekata K, Harada C, Guo X (2009) Interleukin-1 attenuates normal tension glaucoma-like retinal degeneration in EAAC1deficient mice. Neurosci Lett 465:160-164

34. Silva KC, Pinto CC, Biswas SK, de Faria JB, de Faria JM (2007) Hypertension increases retinal inflammation in experimental diabetes: a possible mechanism for aggravation of diabetic retinopathy by hypertension. Curr Eye Res 32:533-541 


\section{Zusammenfassung der Arbeit}

Dissertation zur Erlangung des akademischen Grades Dr. med.

\section{Titel:}

Arteriolenverengung zur Behandlung des Makulaödems im Tiermodel eines

Venenastverschlusses

\section{eingereicht von:}

Martha Patricia Köferl, geboren am 06.11.1983 in Amberg

\section{angefertigt in:}

Universitätsaugenklinik der Medizinischen Fakultät der Universität Leipzig

\section{Betreuer:}

Prof. Dr. med. Peter, Wiedemann, Prof. MUDr. Matus Rehak

\section{Eingereicht:}

Das Makulaödem nach einem retinalen Venenastverschluss (VAV) korreliert in den meisten Fällen mit einem Sehverlust. Derzeit stehen zur Behandlung des Makulaödems drei Therapieverfahren zur Verfügung:

1. Intavitreale Injektionen von anti-VEGF-Medikamenten

2. Applikation von Steroiden in den Glaskörper

3. Die fokale gitterförmige Laserphotokoagulation der Netzhaut

Alle drei Verfahren können unterschiedlich stark ein Makulaödem nach einen stattgefunden VAV reduzieren. Häufig korreliert der Rückgang des retinalen Ödems mit einer Verbesserung der Sehleistung. Alle drei Verfahren haben auch potentielle Risiken und Nebenwirkungen.

So kann es nach der fokalen Laserung zu störenden zentralen Gesichtsfelddefekten kommen. Die Behandlung mit Steroiden und Anti-VEGF-Präparaten muss als Injektion in den 
Glaskörper erfolgen. Allein diese Applikationsform kann z.B. zur Verletzung der Linse, einer Netzhautablösung und einer Endophthalmitis führen. Des Weiteren erfordern beide Verfahren wiederholte Applikationen, die für die Patienten oft eine hohe Anzahl von Arztbesuchen bedeutet. Deshalb wäre eine ideale Behandlung des Makulaödems eine einmalige Behandlung mit möglichst geringen Nebenwirkungen und einer hohen Effizienz.

Eine mögliche Alternative zu den oben genannten Verfahren würde die Arteriolenverengung (AV) (Arterial Crimping) darstellen. Bei dieser Behandlung wird die zuführende Arterie des okkludierten Netzhautgebietes mittels Argonlasers koaguliert und somit der Blutzustrom reduziert. Erste klinische Studien zeigten vielversprechende Ergebnisse. So konnte bei den behandelten Patienten sowohl eine Reduktion des Makulaödems als auch eine Verbesserung der Sehleistung nachgewiesen werden. Allerdings wurden die Wirkungsmechanismen dieses Verfahren bis heute nicht vollständig geklärt.

In der vorgelegten Arbeit wurde die Genexpression von Faktoren, die bei der Entwicklung und Resorption des Makulaödems infolge eines retinalen VAV eine Rolle spielen, untersucht. Des Weiteren wurde das Wirkprinzip der AV zur Behandlung eines VAV analysiert. Alle Experimente wurden in einem Rattenmodel durchgeführt und der VAV mittels einer ArgonLaserphotokoagulation induziert. Die Tiere wurden in drei Gruppen eingeteilt:

1. Gruppe: retinaler VAV ohne Therapie $(\mathrm{N}=32)$

2. Gruppe: retinaler VAV mit Arteriolenverengung $(\mathrm{N}=19)$

3. Gruppe: unbehandelte Kontrollgruppe ( $\mathrm{N}=51)$

Es wurde jeweils an einem Auge der Tiere ein Gefäßverschluss durch Laserkoagulation induziert. Bei der Gruppe, die eine Therapie erhielten, wurde zusätzlich eine Konstriktion der versorgenden Arterie mittels Laser durchgeführt. Die unbehandelten Partneraugen dienten bei allen Tieren als gesunde Kontrollen.

In der Pathogenese eines Makulaödems spielen verschiedene Faktoren eine maßgebliche Rolle. Vascular-Endothelial-Growth-Factor (VEGF) bewirkt eine Ödembildung. Einen gleichen Effekt auf die Ödembildung haben inflammatorische Zytokine wie Interleukin-1beta (IL-1 $\beta$ ) und Interleukin-6 (IL-6). Für die natürliche Resorption von Wasser aus der Netzhaut sind verschiedene Membranproteine wie z.B. die Kaliumkanäle (Kir4.1) und Aquaporine (AQP1, AQP4,) verantwortlich. Kommt es zu einer verminderten Bildung von diesen Proteinen, resultiert dieses ebenfalls in einer Ödembildung. Ein Faktor der ebenfalls die Wassereinlagerung in der Netzhaut reduzieren kann, stellt der Wachstumsfaktor Pigment- 
Epithelium-derived-factor (PEDF) dar.

Die Genexpression der genannten Faktoren wurde mittels real time Polymerase Ketten Reaktion (PCR) separat in der Netzhaut und den Zellen des retinalen Pigmentepithels (RPE) untersucht. Die Bestimmung erfolgte am Tag 1, 3 und 7 nach der VAV-Induktion und am Tag 1 und 3 nach der AV-Behandlung.

Zusammenfassend zeigte sich eine unterschiedliche Expression der genannten Faktoren in Abhängigkeit vom untersuchten Gewebe (Neuroretina und RPE), sowie von der Dauer der durch den VAV induzierten Netzhautischämie.

Die Ergebnisse der Genexpression in der untersuchten Netzhaut nach VAV ergaben folgende zeitabhängige Veränderungen:

1. schnelle vorübergehende Erhöhung der Expression von VEGF mRNA

2. Vermehrte Expression von PEDF mRNA nach drei und sieben Tagen

3. stark verminderte Bildung der mRNA der Kalium-, und Wasserkanäle Kir4.1, AQP4 und AQP1

4. erhöhte Genexpression von den inflammatorischen Zytokinen IL-1 $\beta$ und IL-6.

Die Veränderungen in der Genexpression der Netzhaut bei Zustand nach VAV lassen somit vermuten, dass für die Entstehung eines Netzhautödem sowohl die vaskuläre Leckage (induziert durch VEGF und IL-1 $\beta$ und IL-6) als auch die Flüssigkeitsansammlung des retinalen Gewebes (Herunterregulation der glialen Wasser- und Kalium-Kanäle) verantwortlich ist.

Die Ergebnisse der Genexpression nach einem VAV zeigten in der Netzhaut einen rapiden Anstieg der VEGF-A-Expression nach einem Tag und einen verspäteten Anstieg der PEDFExpression nach drei und sieben Tagen. Die Expression von VEGF-B zeigte in der Netzhaut bei allen untersuchten Zeitpunkten keine signifikanten Unterschiede. In den RPE-Zellen wurde ebenfalls ein Anstieg der VEGF-A mRNA Expression nachgewiesen. Die Expression von VEGF-B war am Tag 1 unverändert, reduzierte sich am Tag 3 und 7 signifikant.

Die starke vorübergehende Erhöhung der VEGF-Expression in der Netzhaut nach VAV lässt sich durch die verursachte Hypoxie und der daraus resultierenden Entzündungsreaktion erklären. Diese wiederum könnte über eine Ausschüttung von IL-1 $\beta$ zur weiteren Vermehrung von VEGF-A beitragen (Vinores et al. 2003; Watanabe et al. 2009). Der Abfall der VEGF-AExpression drei Tage nach einem VAV könnte auf einer vermehrten Bildung von PEDF beruhen, welches zu diesem Zeitpunkt ansteigt. 
Die Expression von Kalium- und Wasserkanälen (Kir4.1, AQP4, AQP1) wurde in der Netzhaut und in den RPE-Zellen am Tag 1 und 3 herunter reguliert. Am Tag 7 normalisierte sich die Expression von allen Kalium- und Wasserkanälen in den RPE-Zellen. Dieser Effekt konnte nicht in der Netzhaut detektiert werden. Hier wurde nur eine Normalisierung der Expression von Kir4.1 verzeichnet.

Um eine mögliche Umverteilung der Membranproteine AQP4, AQP1 und Kir4.1 zu untersuchen, wurden immunhistochemische Analysen durchgeführt. Es zeigte sich kein Effekt des VAV auf das Verteilungsmuster von AQP4 und AQP1. Im Gegensatz dazu kam es zu einer Umverteilung der Lokalisation des Proteins Kir4.1 in der Netzhaut. In den Kontrollen wurde eine Expression von Kir4.1 in der inneren Netzhautschicht (Nervenfaser und Ganglienschicht) und perivaskulär nachgewiesen. Nach VAV wurde eine Verteilung in der gesamten Netzhaut beobachtet.

Die Netzhautexpression der Entzündungszytokine (IL-1ß, IL-6) wurde signifikant hoch reguliert, in den RPE-Zellen war der Expressionsanstieg nur am Tag 1 bei IL-6 sichtbar. Am Tag 7 wurde für beide Entzündungszytokine eine signifikante Reduktion der mRNAExpression beobachtet.

Die Behandlung des VAV durch die AV zeigte unterschiedliche Effekte auf die untersuchten Gene. Die AV hatte keinen Einfluss auf die Genexpression von VEGF-A und VEGF-B. Wie bereits beschrieben kam es auch bei diesen Tieren zu einer vermehrten Bildung der VEGF-AExpression nach einem Tag. Der Effekt war sowohl in der Netzhaut als auch im RPE nachzuweisen. Die VEGF-B mRNA Expression war in der Netzhaut unverändert, im RPE zeigte sich wie bei den unbehandelten Tieren mit VAV eine unveränderte Expression von VEGF-B am Tag 1 und eine Reduktion am 3. und 7. Tag.

Ein ähnliches Ergebnis zeigte sich auch für die Expression von PEDF. Auch hier konnte kein Einfluss der AV auf die mRNA Bildung nachgewiesen werden. Im RPE kam zu einem Anstieg der mRNA Menge an dem Tag 3 und 7.

Im Gegensatz zu dem marginalen Einfluss der AV auf die Genexpression von VEGF und PEDF zeigten sich signifikante Effekte auf die Bildung der mRNA der Membranproteine Kir4 und AQP4. Die AV führte zu einer schnellen Normalisierung der gestörten Genexpression der Kanäle Kir4.1 und AQP4 im RPE. Derselbe Effekt wurde auch für Kir4.1 in der Neuroretina gefunden. Zusätzlich wurde die Überexpression von IL-6 in der Neuroretina durch die AV reduziert. Die AV hatte keinen Einfluss auf die VAV induzierte Umverteilung des Kir4.1 Proteins. 
Die Ergebnisse unserer Experimente zeigten, dass eine AV ein protektiver Faktor gegenüber der Entstehung eines Netzhautödems beim VAV darstellt. Die beschleunigte Wiederherstellung der durch den VAV supprimierten Membranproteine Kir4.1, AQP4 und AQP1 im RPE und von Kir4.1 in der Neuroretina könnte zu einer schnelleren Resorption des Makulaödems beitragen. Des Weiteren ist es denkbar, dass durch die beschleunigte Normalisierung der hochregulierten Expression von IL-6 in der Neuroretina, die retinale Entzündung und das Ausmaß der Gefäßpermeabilität verringert werden. Alle Effekte der AV nach VAV auf die retinale Genexpression wurden nach drei Tagen, aber nicht nach einen Tag beobachtet. Daher kann man den Schluss ziehen, dass der Effekt der AV verzögert eintritt. Es bleibt zu erforschen ob eine Abnahme des hydrostatischen Druckes ein kausativer Faktor ist für die AV induzierte beschleunigte Abnahme des hochregulierten IL-6.

Zusammenfassend führen die hier vorliegenden Ergebnisse zu einem besseren Verständnis der Pathogenese des Makulaödems infolge eines VAV und zeigen, dass die Veränderungen teilweise durch die AV Technik normalisiert werden können. Somit lässt sich spekulieren, dass die AV Behandlung nach weiteren experimentellen und klinischen Studien als Alternative $\mathrm{zu}$ den bisher üblichen Behandlungsmethoden eines Makulaödems bei VAV angewendet werden könnte. 


\section{Literaturverzeichnis}

1. Adamis AP, Shima DT, Yeo KT, Yeo TK, Brown LF, Berse B, D'Amore PA, Folkman J (1993) Synthesis and secretion of vascular permeability factor/vascular endothelial growth factor by human retinal pigment epithelial cells. Biochem Biophys Res Commun. 193(2):631-8

2. Aiello LP, Bursell SE, Clermont A, Duh E, Ishii H, Takagi C, Mori F, Ciulla TA, Ways K, Jirousek M, Smith LE, King GL (1997) Vascular endothelial growth factor-induced retinal permeability is mediated by protein kinase $\mathrm{C}$ in vivo and suppressed by an orally effective beta-isoform-selective inhibitor. Diabetes. 46(9):1473-80

3. Aiello LP, Northrup JM, Keyt BA, Takagi H, Iwamoto MA (1995) Hypoxic regulation of vascular endothelial growth factor in retinal cells. Arch Ophthalmol. 113(12):1538-44

4. Ashton N, Cunha-Vaz JG (1965) Effect of Histamine on the permeability of the ocular vessels. Arch. Ophthalmol 73:211-23

5. Bringmann A, Pannicke T, Grosche J, Francke M, Wiedemann P, Skatchkov SN, Osborne NN, Reichenbach A (2006) Müller cells in the healthy and diseased retina. Prog Retin Eye Res. 25(4):397-424

6. Bringmann A, Reichenbach A, Wiedemann P (2004) Pathomechanisms of cystoid macular edema. Ophthalmic Res. 36(5):241-9

7. Bringmann A, Uckermann O, Pannicke T, Iandiev I, Reichenbach A, Wiedemann P (2005) Neuronal versus glial cell swelling in the ischaemic retina. Acta Ophthalmol Scand 83(5):528-38.

8. BVOS (1984) Argon laser photocoagulation for macular edema in branch vein occlusion. The Branch Vein Occlusion Study Group (1984). Am. J. Ophthalmol. 98(3):271-82

9. BVOS (1986) Argon laser scatter photocoagulation for prevention of and vitreous haemorrhage in branch vein occlusion. A randomized clinical trial. Branch Vein Occlusion Study Group. Arch Ophthalmol 104:34-41

10. Campochiaro PA (2007) Seeing the light: new insights into the molecular pathogenesis of retinal diseases. J Cell Physiol. 213(2):348-54

11. Campochiaro PA, Clark WL, Boyer DS, Heier JS, Brown DM, Vitti R, Kazmi H, Berliner AJ, Erickson K, Chu KW, Soo Y, Cheng Y, Haller JA (2015) Intravitreal 
aflibercept for macular edema following branch retinal vein occlusion: the 24-week results of the VIBRANT study. Ophthalmology. 122(3):538-44

12. Cekiç O, Cakır M, Yazııı AT, Alagöz N, Bozkurt E, Faruk Yılmaz O (2010) A comparison of three different intravitreal treatment modalities of macular edema due to branch retinal vein occlusion. Curr Eye Res. 35(10):925-9

13. CVOS (1993) Central vein occlusion study of photocoagulation. Manual of operations. Central Vein Occlusion Study Group. Online J Curr Clin Trials. Oct 2;Doc No 92

14. Derevjanik NL, Vinores SA, Xiao WH, Mori K, Turon T, Hudish T, Dong S, Campochiaro PA (2002) Quantitative assessment of the integrity of the bloodretinal barrier in mice. Invest Ophthalmol Vis Sci. 43(7):2462-7

15. Dithmar S, Holz FG: Fluoreszenzangiographie in der Augenheilkunde Springer Medizin Verlag Heidelberg 2008 (ISBN: 978-3-540-35223-5)

16. Eichler W, Kuhrt H, Hoffmann S, Wiedemann P, Reichenbach A (2000) VEGF release by retinal glia depends on both oxygen and glucose supply. Neuroreport 11(16):3533-7

17. Erdöl H, Akyol N. (2000) Arterial crimping in branch retinal vein occlusion with macular edema. Acta Ophthalmol Scand. 78(4):456-9

18. Feltgen N, Pielen A, Hansen L, Bertram B, Agostini H, Jaissle GB, Hoerauf H, Stahl A (2010). [Intravitreale Medikamenteneingabe bei retinalem Venenverschluss pathophysiologische Mechanismen und angewandte Substanzen]. Klin Monbl Augenheilkunde 227(9)681-693

19. Finkelstein D (1992) Ischemic macular edema. Recognition and favourable natural history in branch vein occlusion. Arch Ophthalmol. 110(10):1427-34

20. Haller JA, Bandello F, Belfort R Jr, Blumenkranz MS, Gillies M, Heier J, Loewenstein A, Yoon YH, Jacques ML, Jiao J, Li XY, Whitcup SM; OZURDEX GENEVA Study Group (2010). Randomized, sham-controlled trial of dexamethasone intravitreal implant in patients with macular edema due to retinal vein occlusion. Ophthalmology 117(6):1134-1146

21. Haller JA, Bandello F, Belfort R Jr, Blumenkranz MS, Gillies M, Heier J, Loewenstein A, Yoon YH, Jiao J, Li XY, Whitcup SM; Ozurdex GENEVA Study Group (2011). Dexamethasone Intravitreal Implant in Patients with Macular Edema Related to Branch or Central Retinal Vein Occlusion Twelve-Month Study Results. Ophthalmology 118(12):2453-60 
22. Hayreh SS (2005) Prevalent misconceptions about acute retinal vascular occlusive disorders. Prog. Retin Eye Res 24(4):493-519

23. Hayreh SS, Zimmerman MB, Podhajsky P (1994) Incidence of various types of retinal vein occlusion and their recurrence and demographic characteristics. Am. J Ophthalmol. 117(4):429-41

24. Hoeh AE, Ach T, Schaal KB, Scheuerle AF, Dithmar S (2009) Long-term follow-up of OCT-guided bevacizumab treatment of macular edema due to retinal vein occlusion. Graefes Arch. Clin. Exp. Ophthalmol 247(12):1635-41

25. Iandiev I, Pannicke T, Biedermann B, Wiedemann P, Reichenbach A, Bringmann A (2006a) Ischemia-reperfusion alters the immunolocalization of glial aquaporins in rat retina. Neurosci Lett. 408(2):108-12

26. Iandiev I, Pannicke T, Reichenbach A, Wiedemann P, Bringmann A (2007) Diabetes alters the localization of glial aquaporins in rat retina. Neurosci Lett. 421(2):132-6

27. Iandiev I, Tenckhoff S, Pannicke T, Biedermann B, Hollborn M, Wiedemann P, Reichenbach A, Bringmann A (2006b) Differential regulation of Kir4.1 and Kir2.1 expression in the ischemic rat retina. Neurosci Lett. 396(2):97-101

28. Jefferies P, Clemett R, Day T. (1993) An anatomical study of retinal arteriovenous crossings and their role in the pathogenesis of retinal branch vein occlusions. Aust N Z J Ophthalmol. 21(4):213-7

29. Joussen AM, Poulaki V, Le ML, Koizumi K, Esser C, Janicki H, Schraermeyer U, Kociok N, Fauser S, Kirchhof B, Kern TS, Adamis AP (2004) A central role for inflammation in the pathogenesis of diabetic retinopathy. FASEB J.

18(12):1450-2

30. Klein R, Klein BE, Moss SE, Meuer SM (2000) The epidemiology of retinal vein occlusion: the Beaver Dam Eye Study. Trans Am Ophthalmol Soc. 98:133-41; discussion 141-3

31. L'Esperance F (1975) Ocular Photocoagulation. A Stereoscopic Atlas. St. Louis: CV Mosby, pp 215-222.

32. Luna JD, Chan CC, Derevjanik NL, Mahlow J, Chiu C, Peng B, Tobe T, Campochiaro PA, Vinores SA (1997) Blood-retinal barrier (BRB) breakdown in experimental autoimmune uveoretinitis: comparison with vascular endothelial growth factor, tumor necrosis factor alpha, and interleukin-1beta-mediated breakdown. J Neurosci Res. 49(3):268-80 
33. McCannel CA (2011) Meta-analysis of endoopthalmitits after intravitreal injection of anti-vascular endothelial growth factor agents: causative organisms and possible prevention strategies. Retina (Philadelphia, Pa.) 31(4):654-661.

34. Miller JW, Adamis AP, Shima DT, D'Amore PA, Moulton RS, O’Reilly MS, Folkman J, Dvorak HF, BrownLF, Berse B, et al. (1994) Vascular endothelial growth factor/vascular permeability factor is temporally and spatially correlated with ocular angiogenesis in a primate model. In: Am J Pathol. 145(3):574-84

35. Mitchell P, Smith W, Chang A (1996) Prevalence and associations of retinal vein occlusion in Australia. The Blue Mountains Eye Study. Arch. Ophthalmol 114(10):1243-7

36. Mori F, Hikichi T, Takahashi J, Nagaoka T, Yoshida A (2002) Dysfunction of active transport of blood-retinal barrier in patients with clinically significant macular edema in type 2 diabetes. Diabetes Care. 25(7):1248-9

37. Nagelhus EA, Horio Y, Inanobe A, Fujita A, Haug FM, Nielsen S, Kurachi Y, Ottersen OP (1999) Immunogold evidence suggests that coupling of $\mathrm{K}+$ siphoning and water transport in rat retinal Müller cells is mediated by a coenrichment of Kir4.1 and AQP4 in specific membrane domains. Glia 26(1):47-54

38. Nehme A, Edelman J (2008) Dexamethasone inhibits high glucose-, TNF-alpha-, and IL-1beta-induced secretion of inflammatory and angiogenic mediators from retinal microvascular pericytes. Invest Ophthalmol Vis Sci. 49(5):2030-8

39. Noma H, Funatsu H, Mimura T, Harino S, Hori S (2009) Vitreous levels of interleukin-6 and vascular endothelial growth factor in macular edema with central retinal vein occlusion. Ophthalmology 116(1):87-93

40. Pannicke T, Iandiev I, Uckermann O, Biedermann B, Kutzera F, Wiedemann P, Wolburg H, Reichenbach A, Bringmann A (2004) A potassium channel-linked mechanism of glial cell swelling in the postischemic retina. Mol Cell Neurosci. 26(4):493-502

41. Park SP, Ahn JK (2008) Changes of aqueous vascular endothelial growth factor and interleukin- 6 after intravitreal triamcinolone for branch retinal vein occlusion. Clin Experiment Ophthalmol. 36(9):831-5

42. Rehak M, Hollborn M, Iandiev I, Pannicke T, Karl A, Wurm A, Kohen L, Reichenbach A, Wiedemann P, Bringmann A (2009) Retinal gene expression and Müller cell responses after branch retinal vein occlusion in the rat. Invest Ophthalmol Vis Sci. 50(5):2359-67 
43. Rehak M, Wiedemann P (2010) Retinal vein thrombosis: pathogenesis and management. J Thromb Haemost: 8(9):1886-94

44. Rehák J, Dusek L, Sin M, Babkova B, Pracharova Z, Rehak M (2014) Long term visual outcome after arteriolar constriction in patients with branch retinal vein occlusion. Biomed Pap Med Fac Univ Palacky Olomouc Czech Repub. 158(4):577-82

45. Rehák J, Rehak M (2008) Branch retinal vein occlusion: pathogenesis, visual prognosis, and treatment modalities. Curr Eye Res. 33(2):111-31

46. Robinson GS, Ju M, Shih SC, Xu X, McMahon G, Caldwell RB, Smith LE (2001) Nonvascular role for VEGF: VEGFR-1, 2 activities are critical for neural retinal development. FASEB J. 15(7):1215-7

47. Rogers S, McIntosh RL, Cheung N et al. (2010) The prevalence of retinal vein occlusion: pooled data from population studies from the United States, Europe, Asia, and Australia. Ophthalmology. 117(2):313-9.e1

48. Rouvas A, Petrou P, Ntouraki A, Douvali M, Ladas I, Vergados I (2010) Intravitreal ranibizumab (Lucentis) for branch retinal vein occlusion-induced macular edema: nine-month results of a prospective study. Retina. 30(6):893-902

49. Scott IU, Ip MS, VanVeldhuisen PC et al. (2009) A randomized trial comparing the efficacy and safety of intravitreal triamcinolone with standard care to treat vision loss associated with macular Edema secondary to branch retinal vein occlusion: the Standard Care vs Corticosteroid for Retinal Vein Occlusion (SCORE) study report 6. Arch Ophthalmol. 127(9):1115-28

50. Stamer WD, Bok D, Hu J, Jaffe GJ, McKay BS (2003) Aquaporin-1 channels in human retinal pigment epithelium: role in transepithelial water movement. Invest. Ophthalmol. Vis. Sci 44(6):2803-8

51. Vinores SA, Sen H, Campochiaro PA (1992) An adenosine agonist and prostaglandin E1 cause breakdown of the blood-retinal barrier by opening tight junctions between vascular endothelial cells. Invest. Ophthalmol. Vis. Sci 33(6):1870-8

52. Vinores SA, Xiao WH, Zimmerman R, Whitcup SM, Wawrousek EF (2003) Upregulation of vascular endothelial growth factor (VEGF) in the retinas of transgenic mice overexpressing interleukin-1beta (IL-1beta) in the lens and mice undergoing retinal degeneration. Histol Histopathol. 18(3):797-810

53. Watanabe K, Zhang XY, Kitagawa K, Yunoki T, Hayashi A (2009) The effect of clonidine on VEGF expression in human retinal pigment epithelial cells (ARPE-19). Graefes Arch Clin Exp Ophthalmol. 247(2):207-13 
54. Yau JW, Lee P, Wong TY, Best J, Jenkins A (2008) Retinal vein occlusion: an approach to diagnosis, systemic risk factors and management. Intern Med J.

38:(12):904-10

55. Zhang F, Tang Z, Hou X, Lennartsson J, Li Y, Koch AW, Scotney P, Lee C, Arjunan P, Dong L, Kumar A, Rissanen TT, Wang B, Nagai N, Fons P, Fariss R, Zhang Y, Wawrousek E, Tansey G, Raber J, Fong GH, Ding H, Greenberg DA, Becker KG, Herbert JM, Nash A, Yla-Herttuala S, Cao Y, Watts RJ, Li X (2009) VEGF-B is dispensable for blood vessel growth but critical for their survival, and VEGF-B targeting inhibits pathological angiogenesis. Proc Natl Acad Sci USA. 106(15):6152-7

56. Zhang SX, Wang JJ, Gao G, Parke K, Ma JX (2006) Pigment epithelium-derived factor downregulates vascular endothelial growth factor (VEGF) expression and inhibits VEGF-VEGF receptor 2 binding in diabetic retinopathy. J Mol Endocrinol. $37(1): 1-12$ 


\section{Darstellung des eigenen Beitrages}

In der vorgelegten Publikation mit dem Titel: "Effects of arteriolar constriction on retinal gene expression and Muiller cell responses in a rat model of branch retinal vein occlusion" habe ich folgende Arbeiten selbststandig und alleine durchgefuhrt:

-Separation der Netzhaut von den RPE-Zellen der enukleierten Augen

-Extraktion der mRNA

-Durchfiuhrung der PCR-Diagnostik

-Statistische Auswertung

Die Tierexperimente wie die Laserphotokoagulation, Fluoresenzangiographie, die Arteriolenverengung und die Enukleation đer Augen erfolgte gemeinsan mit Prof. Dr. MUDr. M. Rehak Ph.D. Zusătzlich wurden im Zusammenhang der Experimente ergänzende weitere Versuche wie die Immunfärbung zusammen mit PD Iandiev aus der Universitäts-Augenklinik Leipzig durchgefuhit. Ich habe die Daten ausgewertet und für die Publikation vorbereitet. Außerdem war ich maßgeblich an der Interpretation der Ergebnisse beteiligt. Die Publikation und Revision der Ergebnisse wurde geneinsam mit Prof. Dr. MUDr. M. Rehak Ph.D erstellt.

Hiermit erklären wir, dass Frau Martha Patricia Köferl an der Publikation:

"Köferl P, Hollborn M, Rehák J, Iandiev I, Dukic-Stefanovic S, Wiedemann P, Kohen L, Bringmann A, Rehak M. Effects of arteriolar constriction on retinal gene expression and Müller cell responses in a rat model of branch retinal vein occlusion. Graefes Arch Clin Exp Ophthalmol. 2014; 252: 257-65" den wesentlichen Beitrag geleistet hat, der eine Erstautorenschaft rechtfertigt. Sie war substanziell an der Konzeption an der Arbeit beteiligt und den größten Teil der Experimente durchgefúhrt, die Daten ausgewertet und für die Publikation vorbereitet. Außerdem war Frau Köferl maßgeblich an der Interpretation der Ergebnisse und Erstellung des Maruskriptes mitbeteiligt,

Martha Patricia Köferl
Klinik fur Augenheilkundef $y$ nivelsitätsklinikum Erlangen-Nurnberg

Dr. rer, nat. Margrit Hollborn

Klinik für Augenheilkunde, Universitätsklinikum Leipzig

Professor Jiř́ Řehák M.D. Aứ̆h

Palacký University Faculty of Medicine Olomouc and University Hospital Olomouc

PD Dr. med. habil. Yanors Iandiev

Klinik für Augenheilkunde, Universitätsklinikum Leipzig

Dr. Sladjana Dukic-Stefanovic

Helmholtz-Zentrum Dresden-Rossendorf

Prof. Dr. med. Peter Wiedemann

Klinik für Augenheilkunde, Universitäts/ kignkun Leipzig

Prof. Dr. med. Leon Kohen

Klinik fur Augenheilkunde, Helios Klinikun Aue

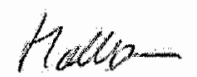

Prof. Dr. rèr. nat. Andreas Bringmann

Klinik für Augenheilkunde, Universitätsklinikum Leipzig

Prof. MUDr. Matus Rehak, Ph.D.

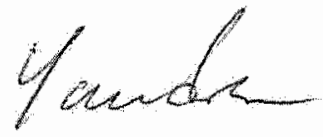

Klinik für Augenheilkunde, Universitätskliniłcam Leipzig
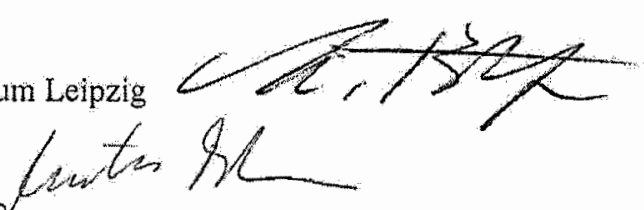


\section{Selbstständigkeitserklärung}

\section{$\underline{\text { Erklärung über die eigenständige Abfassung der Arbeit }}$}

Hiermit erkläre ich, dass ich die vorliegende Arbeit selbständig und ohne unzulässige Hilfe oder Benutzung anderer als der angegebenen Hilfsmittel angefertigt habe. Ich versichere, dass Dritte von mir weder unmittelbar noch mittelbar eine Vergütung oder geldwerte Leistungen für Arbeiten erhalten haben, die im Zusammenhang mit dem Inhalt der vorgelegten Dissertation stehen, und dass die vorgelegte Arbeit weder im Inland noch im Ausland in gleicher oder ähnlicher Form einer anderen Prüfungsbehörde zum Zweck einer Promotion oder eines anderen Prüfungsverfahrens vorgelegt wurde. Alles aus anderen Quellen und von anderen Personen übernommene Material, das in der Arbeit verwendet wurde oder auf das direkt Bezug genommen wird, wurde als solches kenntlich gemacht. Insbesondere wurden alle Personen genannt, die direkt an der Entstehung der vorliegenden Arbeit beteiligt waren. Die aktuellen gesetzlichen Vorgaben in Bezug auf die Zulassung der klinischen Studien, die Bestimmungen des Tierschutzgesetzes, die Bestimmungen des Gentechnikgesetzes und die allgemeinen Datenschutzbestimmungen wurden eingehalten. Ich versichere, dass ich die Regelungen der Satzung der Universität Leipzig zur Sicherung guter wissenschaftlicher Praxis kenne und eingehalten habe.

Datum

Unterschrift 


\section{Danksagung}

Ganz herzlich bedanken möchte ich mich bei Herrn Professor MUDr. Matus Rehak für seine großartige Unterstützung und erstklassige Betreuung.

Ich danke Herrn Professor Peter Wiedemann für die Möglichkeit dessen Forschungslabore und technischen Ausstattungen für die Durchführung meiner Versuche nutzen zu dürfen.

Für die exzellente technische Assistenz bedanke ich mich herzlichst bei Ute Weinbrecht und Franziska Rickers.

Tief verbunden und sehr dankbar bin ich Ulli für seine unglaubliche hilfreiche Unterstützung bei der Anfertigung dieser Doktorarbeit.

Ein ganz besonderer Dank gebührt meinen Eltern und Geschwistern, die mich auf meinem gesamten Weg unterstützt haben. 